\title{
Climate and marine biogeochemistry during the Holocene from transient model simulations
}

\author{
Joachim Segschneider ${ }^{1}$, Birgit Schneider ${ }^{1}$, and Vyacheslav Khon ${ }^{1,2, a}$ \\ ${ }^{1}$ Institute of Geosciences, Christian-Albrechts University of Kiel, Ludewig-Meyn-Str. 10, 24118 Kiel, Germany \\ ${ }^{2}$ A. M. Obukhov Institute of Atmospheric Physics, Russian Academy of Sciences, Moscow, Russia \\ anow at: GEOMAR Helmholtz Centre for Ocean Research Kiel, Kiel, Germany
}

Correspondence: Joachim Segschneider (joachim.segschneider@ifg.uni-kiel.de)

Received: 22 December 2017 - Discussion started: 4 January 2018

Revised: 27 April 2018 - Accepted: 2 May 2018 - Published: 1 June 2018

\begin{abstract}
Climate and marine biogeochemistry changes over the Holocene are investigated based on transient global climate and biogeochemistry model simulations over the last 9500 years. The simulations are forced by accelerated and non-accelerated orbital parameters, respectively, and atmospheric $p \mathrm{CO}_{2}, \mathrm{CH}_{4}$, and $\mathrm{N}_{2} \mathrm{O}$. The analysis focusses on key climatic parameters of relevance to the marine biogeochemistry, and on the physical and biogeochemical processes that drive atmosphere-ocean carbon fluxes and changes in the oxygen minimum zones (OMZs). The simulated global mean ocean temperature is characterized by a mid-Holocene cooling and a late Holocene warming, a common feature among Holocene climate simulations which, however, contradicts a proxy-derived mid-Holocene climate optimum. As the most significant result, and only in the non-accelerated simulation, we find a substantial increase in volume of the OMZ in the eastern equatorial Pacific (EEP) continuing into the late Holocene. The concurrent increase in apparent oxygen utilization (AOU) and age of the water mass within the EEP OMZ can be attributed to a weakening of the deep northward inflow into the Pacific. This results in a large-scale mid-tolate Holocene increase in AOU in most of the Pacific and hence the source regions of the EEP OMZ waters. The simulated expansion of the EEP OMZ raises the question of whether the deoxygenation that has been observed over the last 5 decades could be a - perhaps accelerated - continuation of an orbitally driven decline in oxygen. Changes in global mean biological production and export of detritus remain of the order of $10 \%$, with generally lower values in the midHolocene. The simulated atmosphere-ocean $\mathrm{CO}_{2}$ flux would
\end{abstract}

result in atmospheric $p \mathrm{CO}_{2}$ changes of similar magnitudes to those observed for the Holocene, but with different timing. More technically, as the increase in EEP OMZ volume can only be simulated with the non-accelerated model simulation, non-accelerated model simulations are required for an analysis of the marine biogeochemistry in the Holocene. Notably, the long control experiment also displays similar magnitude variability to the transient experiment for some parameters. This indicates that also long control runs are required when investigating Holocene climate and marine biogeochemistry, and that some of the Holocene variations could be attributed to internal variability of the atmosphere-ocean system.

\section{Introduction}

Numerical models that combine the ocean circulation and marine biogeochemistry have been developed since the 1980s (e.g. Maier-Reimer et al., 1993, 2005; Maier-Reimer, 1993; Six and Maier-Reimer, 1996). Few studies of marine carbon cycle variability during the Holocene have been performed, however, as the focus of marine carbon cycle research has been more on recent and future climate change related carbon cycle changes (e.g. Maier-Reimer and Hasselmann, 1987; Maier-Reimer et al., 1996), and glacialinterglacial changes (e.g. Heinze et al., 1991; Brovkin et al., 2016; Bopp et al., 2017). However, 1000-year long transient climate experiments have been performed for the last millennium with comprehensive Earth system models that include 
the marine carbon cycle (e.g. Jungclaus et al., 2010; Brovkin et al., 2010), and more recently the CMIP5/PMIP3 Millennium experiments (Atwood et al., 2016; Lehner et al., 2015).

Of the many features that characterize the biogeochemical system in the ocean, here we will concentrate on oxygen minimum zones (OMZs), atmosphere-ocean carbon fluxes, and the marine ecosystem. OMZs have received particular attention in the recent past. This is in large part due to the observation that in the last 5 decades, a general deoxygenation of the world's ocean and an intensification of the ocean's main OMZs have occurred (e.g. Stramma et al., 2008; Karstensen et al., 2008; Schmidtko et al., 2017). A further decrease in oceanic $\mathrm{O}_{2}$ concentrations has been projected for the future with numerical models (e.g. Matear and Hirst, 2003; Cocco et al., 2013; Bopp et al., 2013) as a consequence of anthropogenic climate change. Knowing the past variations of the OMZ extent and oxygen is, therefore, of immediate relevance to estimate the importance of the observed and projected deoxygenation (e.g. Bopp et al., 2017).

A few studies that investigate past oxygen variations have already been performed: based on a model study with an intermediate complexity model to investigate glacialinterglacial variations of oxygen, Schmittner et al. (2007) found a causal relationship of Indian and Pacific Ocean oxygen abundance and a shut-down of the Atlantic Meridional Overturning Circulation (AMOC). In their experiments, AMOC variability was generated by freshwater perturbations. An attempt to better understand the currently observed and future projected expansion of the OMZ based on paleo-oceanographic observations (Moffitt et al., 2015) indicates an expansion of the major OMZs in the world ocean concurrent with the warming since the last deglaciation (18$11 \mathrm{kyr}$ BP, kilo years before present). This is based on estimates of seafloor deoxygenation using snapshots at 18,13 , 10 , and 4 kyr BP. Bopp et al. (2017) investigated oxygen variability from the last glacial maximum (LGM) into the future based on CMIP5 simulations (PiControl, the historical and future periods) and time-slice simulations of the last LGM (21 kyr BP) and the mid-Holocene (6 kyr BP).

Although the focus of this paper is on marine biogeochemistry, it is mainly the changes in climate that are driving the changes in marine biogeochemistry. Hence, some characteristics of the Holocene climate variability need to be addressed. Model-based investigations of Holocene climate are performed under the auspices of the Paleo Model Intercomparison Project (PMIP, Braconnot et al., 2012). Initially, numerical model time-slice experiments were used to simulate the climate at specific time intervals, typically $9.5 \mathrm{kyr}, 6 \mathrm{kyr}$, and $0 \mathrm{kyr}$ BP. The simulated climate and its variability have been compared to proxy data (e.g. Leduc et al., 2010; Emile-Geay et al., 2016). Also, transient experiments over the entire Holocene have been performed, mainly with accelerated orbital forcing to save computing time (Lorenz and Lohmann, 2004; Varma et al., 2012; Jin et al., 2014), or coupled atmosphere-ocean intermediate complexity models with non-accelerated forcing (Renssen et al., 2005, 2009; Blaschek et al., 2015). Longer model simulations also exist for Earth system models of intermediate complexity (EMICS), such as described in Brovkin et al. (2016) for the last $8 \mathrm{kyr}$, and for 6 to $0 \mathrm{kyr}$ BP with a comprehensive ocean-atmosphere-land biosphere model but with orbital forcing only (Fischer and Jungclaus, 2011). The longest non-accelerated climate simulation with a comprehensive model is the Tra-CE $21 \mathrm{ka}$ model experiment with the Climate Community System Model 3 for the last $21 \mathrm{kyr}$ (Liu et al., 2014).

A second source of information about climate variability during the Holocene comes from proxy data. A concerted effort to synthesize these estimates by the PAGES2K project has resulted in a temperature reconstruction over the last 2000 years at a fairly high temporal resolution (PAGES 2k Consortium, 2013). In this reconstruction, the global mean surface air temperature is analysed to cool by about $0.3^{\circ} \mathrm{C}$ between 1000 and $1900 \mathrm{AD}$, followed by a sharp increase in temperature. Before $1000 \mathrm{AD}$ the temperature is fairly constant, at about $0.1^{\circ} \mathrm{C}$ colder than the $1961-1990$ average.

Wanner et al. (2008) also provide a comprehensive overview of the globally collected proxy-based climate evolution for the last 6000 years together with some instructive plots of the insolation changes during that period based on Laskar et al. (2004). For land-based proxies the authors consistently find a decrease in temperatures from $6 \mathrm{kyr}$ BP until now, with different amplitude, but for the ocean this is more heterogenous (Wanner et al., 2008, Fig. 2). For example, the sea surface temperature (SST) displays an increase with time in the subtropical Atlantic, whereas SST decreases in line with the land surface records in the western Pacific and in the North Atlantic (see also Marchal et al., 2002).

A continuous reconstruction of temperatures for the entire Holocene, i.e. the past 11300 years, albeit with lower temporal resolution before the PAGES2K period, has been assembled by Marcott et al. (2013). In their reconstruction, global mean surface air temperature increases by about $0.6^{\circ} \mathrm{C}$ between 11.3 and $9 \mathrm{kyr} \mathrm{BP}$ to $0.4^{\circ} \mathrm{C}$ warmer than present (as defined by the 1961-1990 CE mean). After 6 kyr BP temperatures slowly decrease by $0.4^{\circ} \mathrm{C}$ until $2 \mathrm{kyr} \mathrm{BP}$ and are relatively stable for 1000 years. This is followed by a relatively fast decrease beginning around $1 \mathrm{kyr} B \mathrm{PP}$ of $0.3^{\circ} \mathrm{C}$, in agreement with the PAGES2K data and an increase to presentday temperatures in the last few hundred years before present (Marcott et al., 2013, Fig. 1a-f).

Model simulations and proxy-based estimates of past climate variability apparently show some disagreement (Liu et al., 2014), and the model simulations described here make no exception. One reason may be a different behaviour of land and ocean, as e.g. the PMIP2 model simulations in Wanner et al. (2008) show warmer mid-Holocene temperatures over land, in particular over Eurasia, whereas there is little SST difference between $6 \mathrm{kyr}$ BP and modern values. Also, on shorter timescales there are discrepancies between model 
results and proxy-based records. For example, proxy-based estimates indicate changing El Niño-Southern Oscillation (ENSO) related variability during the Holocene that cannot be reproduced by most of the PMIP models (Emile-Geay et al., 2016). Also, the proxy-derived inverse relationship between ENSO variability and the amplitude of the seasonal cycle is not picked up by most of the models (Emile-Geay et al., 2016, Fig. 3). The reasons for the mismatch in proxybased and model-simulated Holocene climate variability, despite some efforts in the PMIP community, have yet to be established.

In this paper we aim at closing the gap between glacialinterglacial and future greenhouse gas (GHG) driven simulations of climate and the marine carbon cycle and earlier timeslice experiments of the Holocene. Given the differences in simulated and proxy-derived climate evolution over the Holocene, this study should be regarded as a sensitivity study to orbital and GHG forcing. Following earlier time-slice experiments with a coupled atmosphere-ocean-sea-ice climate model and a marine biogeochemistry model (Xu et al., 2015), here we use transient model simulations with a comprehensive model system that cover the last $9.5 \mathrm{kyr}$ of the Holocene. In particular, we investigate the temporal evolution of some of the key elements of the simulated climate that are important drivers of marine biogeochemistry variations, such as SST and AMOC. For the marine carbon cycle we focus on global values of primary production, export production, and calcite export, all of which can result in atmosphereocean $\mathrm{CO}_{2}$ flux and $\mathrm{OMZ}$ variations. Based on these results we analyse and discuss changes in the OMZs, in particular in the eastern equatorial Pacific (EEP) but also in the Atlantic and the Arabian Sea, the integrated effect of changes in the atmosphere-ocean $\mathrm{CO}_{2}$ flux, and changes in the marine ecosystem.

In addition we want to address the more technical question to what extent simulations with accelerated orbital forcing are suitable for Holocene marine biogeochemistry simulations. In the accelerated-forcing experiments, the change in orbital parameters between 2 model years corresponds to a 10-year step in the real orbital forcing (see Sect. 2.2.1). For climate simulations, the sensitivity to accelerated vs. non-accelerated forcing has recently been investigated for the last two interglacials (130-120 and 9-2 kyr BP, Varma et al., 2016), indicating that non-accelerated experiments differ from accelerated experiments in the representation of Holocene climate variability at the higher latitudes of both hemispheres, while the behaviour is more similar at low latitudes. A different temporal evolution was also found for the deep ocean temperature, with the non-accelerated experiment displaying a larger variation. Here we perform and analyse simulations of the marine biogeochemistry of the Holocene forced by an accelerated and a non-accelerated climate model simulation of the Holocene.

We will first describe the numerical models, the experiment set-up, and characteristics of the time-varying forcing in Sect. 2, report the results for climatic and biogeochemical variables in Sect. 3, and discuss the results and implications for future research in Sect. 4.

\section{Model description and experiment set-up}

\subsection{Models}

\subsubsection{The Kiel Climate Model (KCM)}

Oceanic physical conditions are obtained from the KCM (the Kiel Climate Model, Park and Latif, 2008; Park et al., 2009) a global coupled climate model, in particular from NEMO/OPA9 (Madec, 2008), which comprises the oceanic component of KCM and includes the LIM2 sea-ice model (Fichefet and Morales Maqueda, 1997). The atmospheric component is ECHAM5 (Roeckner et al., 2003). The spatial configuration for ECHAM5 is T31L19, and for NEMO the ORCA2 configuration is chosen, i.e. a tripolar grid with a nominal resolution of $2^{\circ} \times 2^{\circ}$ and a meridional refinement to $0.5^{\circ}$ near the Equator and 31 layers with a finer resolution in the upper water column. The upper $100 \mathrm{~m}$ are resolved by 10 layers, and below the euphotic zone there are 20 layers with increasing thickness up to a maximum of $500 \mathrm{~m}$ for the deepest layer.

$\mathrm{KCM}$ has previously been used to conduct and analyse time-slice simulations of the pre-industrial and midHolocene climate and hydrological cycle (Schneider et al., 2010; Khon et al., 2010, 2012; Salau et al., 2012) and contributed to PMIP3 (e.g. Emile-Geay et al., 2016). More recently, orbital forcing (eccentricity, obliquity, and precession) were varied continuously over the last 9500 years of the Holocene according to the standard protocol of PMIP (Braconnot et al., 2008). This forcing was accelerated by a factor of 10 , resulting in a transient model experiment of 950 model years for the Holocene (Jin et al., 2014). Here, in additional KCM experiments, the forcing is non-accelerated, so that the Holocene is represented by 9500 model years starting from 9.5 kyr BP (see Sect. 2.2.1 for the experiment description).

\subsubsection{Pelagic Interactions Scheme for Carbon and Ecosystem Studies (PISCES)}

Monthly mean fields of temperature, salinity, and the velocity from the KCM experiment were used in offline mode to force a global model of the marine biogeochemistry (PISCES, Aumont et al., 2003).

Since the description of PISCES in Aumont et al. (2003) is quite comprehensive, we restrict the model description to the most relevant parts for our investigation. Sources of oceanic oxygen are gas exchange with the atmosphere at the surface, and biological production in the euphotic zone. Oxygen-consuming heterotrophic aerobic remineralization of dissolved organic carbon (DOC) and particulate organic carbon (POC) is simulated over the whole water column, i.e. 
also in the euphotic layer. Remineralization depends on local temperature and $\mathrm{O}_{2}$ concentration. For an increase of $10^{\circ} \mathrm{C}$ the rate increases by a factor of $1.8\left(Q_{10}=1.8\right)$. Remineralization is reduced for $\mathrm{O}_{2}$ concentrations below $6 \mu \mathrm{mol} \mathrm{L} \mathrm{L}^{-1}$.

Primary production is simulated by two phytoplankton groups representing nanophytoplankton and diatoms. Growth rates are based on temperature, the availability of light, the nutrients $\mathrm{P}$ and $\mathrm{N}$ (both as nitrate and ammonium), $\mathrm{Si}$ (for diatoms), and the micronutrient $\mathrm{Fe}$. The elemental ratios of iron, chlorophyll, and silicate within diatoms are computed prognostically based on the surrounding water's concentration of nutrients. Otherwise elemental ratios are constant following the Redfield ratios. Photosynthetically available radiation (PAR) is computed from the short-wave radiation passed from ECHAM to NEMO. Sea ice is assumed to reflect all incoming radiation, so there is no biological production in areas that are completely sea-ice-covered (i.e. where the sea-ice fraction is equal to 1 ).

There are three non-living components of organic carbon in PISCES: semi-labile DOC, as well as large and small POC, which are fuelled by mortality, aggregation, fecal pellet production, and grazing. In the standard version of PISCES, large and small POC sinks to the sea floor at respective settling velocities of 2 and $50 \mathrm{~m} \mathrm{~d}^{-1}$. For large POC, the settling velocity increases further with depth. In the model version employed here, the simulation of the settling velocity of large detritus is formulated, allowing for the ballast effect of calcite and opal shells according to Gehlen et al. (2006). The settling velocity of small POC remains constant at $2 \mathrm{~m} \mathrm{~d}^{-1}$. In most areas and at most depths, the ballast parameterization leads to a reduction of the settling velocity for large POC compared to the (50 $\mathrm{m} \mathrm{d}^{-1}$ and more) standard version. The new formulation of the settling velocity for large POC generally improved the oxygen fields of the KCM-driven PISCES simulation when compared to modern-day WOA data (Garcia et al., 2013), in particular in the EEP (see Appendix A for a comparison of observed and simulated oxygen distributions and a sensitivity of the OMZ volume to the $\mathrm{O}_{2}$ threshold). Note that the ballast parameterization was not part of the PISCES version used in Xu et al. (2015), and therefore the mean state of the EEP OMZ differs between the experiments of Xu et al. (2015) and the ones described here.

We also added an age tracer to PISCES. The age tracer is set to zero at surface grid points, and then the age increases with model time elsewhere. Advection and mixing are also applied to the age tracer.

\subsection{Experiment set-up}

\subsubsection{KCM - greenhouse gases and astronomical forcing}

As GHG and orbital forcing are the boundary conditions driving the forced variations in the KCM experiments, we describe this forcing in a little more detail. We do not take into account changes in total solar irradiance (TSI), sea level, changes in ice sheets (neither topography nor albedo), freshwater input into the North Atlantic, or volcanic aerosols.

Greenhouse gas concentrations were obtained from the PMIP database (https://www.paleo.bristol.ac.uk/ ggdjl/ pmip/pmip_hol_lig_gases.txt; last access: 22 May 2018) based on ice cores from the EPICA site (Augustin et al., 2004) and are displayed in Fig. 1a). Prescribed atmospheric $\mathrm{CO}_{2}$ concentration varied from $263.7 \mathrm{ppm}$ at the beginning of the Holocene, decreased to $260 \mathrm{ppm}$ around $7 \mathrm{kyr} \mathrm{BP}$ in the mid-Holocene, and then increased to about $274 \mathrm{ppm}$ for the present-day pre-industrial conditions (based on Indermühle et al., 1999). $\mathrm{CH}_{4}$ varied from $678.8 \mathrm{ppb}$ in the early Holocene to $580 \mathrm{ppb}$ around $5 \mathrm{kyr} \mathrm{BP}$, slowly increasing afterwards to $650 \mathrm{ppb}$ around $0.5 \mathrm{kyr} \mathrm{BP}$, followed by a steeper increase to $805 \mathrm{ppb}$ during the last 500 years of the Holocene, reflecting early land-use change. $\mathrm{N}_{2} \mathrm{O}$ variations were smaller, from $260.6 \mathrm{ppb}$ in the early Holocene to $267 \mathrm{ppb}$ around $2.5 \mathrm{kyr} \mathrm{BP}$.

Eccentricity remained fairly constant at a value of 0.02 over the entire Holocene. The precessional index increased from -0.015 to 0.02 , and the obliquity decreased from about 24.2 to $23.5^{\circ}$. In general, this leads to less insolation during Northern Hemisphere summer and more insolation in Southern Hemisphere summer: solar radiation at the top of the atmosphere (TOA) in June decreased during the Holocene from 9.5 to $0 \mathrm{kyr}$ BP by about $25 \mathrm{Wm}^{-2}$ at the Equator, and $45 \mathrm{Wm}^{-2}$ at $60^{\circ} \mathrm{N}$. In the Southern Hemisphere, the decrease is up to $10 \mathrm{Wm}^{-2}$ at $30^{\circ} \mathrm{S}$, and at $60^{\circ} \mathrm{S}$ there is a weak increase of a few $\mathrm{Wm}^{-2}$. In December the insolation is stronger for $0 \mathrm{kyr} \mathrm{BP}$ than for $9.5 \mathrm{kyr} \mathrm{BP}$ by up to $30 \mathrm{Wm}^{-2}$ at $30^{\circ} \mathrm{S}$ and about $5 \mathrm{Wm}^{-2}$ at $60^{\circ} \mathrm{N}$. See also Jin et al. (2014, Fig. 2) and Wanner et al. (2008, Fig. 6) for changes in solar radiation at the top of the atmosphere vs. time for different latitudes and summer/winter, based on Berger and Loutre (1991) and Laskar et al. (2004), respectively.

We note that the total annual radiation driven by precession changes remains fairly constant at each latitude and globally, whereas obliquity changes cause changes also in the annual mean insolation (see e.g. Fig.1b in Schneider et al., 2010). These annual mean changes in TOA insolation from 9.5 to $0 \mathrm{kyr} \mathrm{BP}$ are a decrease of around $5 \mathrm{Wm}^{-2}$ at the poles and an increase of $1 \mathrm{Wm}^{-2}$ at the Equator, thereby potentially increasing the latitudinal temperature gradient.

For our analyses that focus on ocean physical conditions and marine biogeochemistry, however, we need to consider the TOA forcing as filtered by the atmosphere, i.e. at the sea surface. In Fig. $1 \mathrm{~b}$ annual and zonal mean anomalies of short-wave radiation (SWR) at the ocean and sea-ice surface are displayed as a Hovmöller diagram. These annual mean anomalies are somewhat different from the TOA anomalies, but more relevant for understanding the simulated SST evolution and changes in PAR. In the early Holocene, negative anomalies of -1 to $-3 \mathrm{Wm}^{-2}$ develop at high latitudes of mainly the Southern Hemisphere. In the mid-Holocene neg- 
(a)

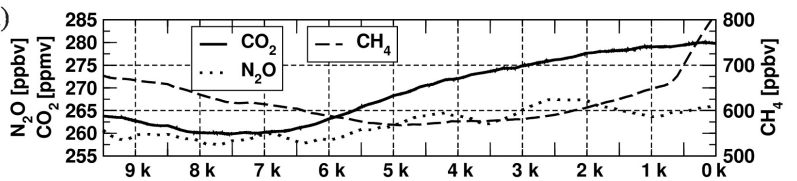

(b)

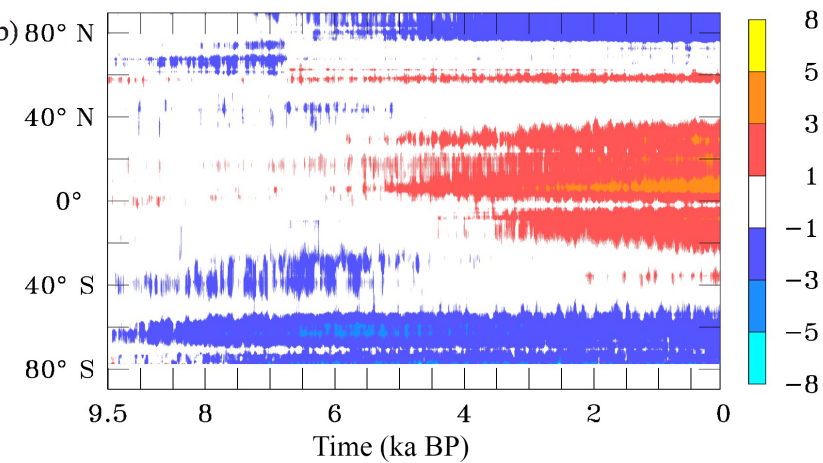

Figure 1. Forcing for the KCM-HOL and BGC-HOL experiments: (a) Holocene atmospheric greenhouse gas concentrations $\left(\mathrm{CO}_{2}\right.$, ppm; $\mathrm{CH}_{4}$ and $\mathrm{N}_{2} \mathrm{O}$, ppb) derived from EPICA ice cores (Augustin et al., 2004) and provided by PMIP and (b) short-wave radiative forcing at the sea/sea-ice surface in $\mathrm{W} \mathrm{m}^{-2}$ for the BGC-HOL experiment as computed in experiment $\mathrm{KCM}-\mathrm{HOL}$ (i.e. the astronomical TOA changes over the Holocene as shown in Jin et al., 2014 filtered by ECHAM5, the atmospheric component of KCM). Hovmöller diagram of the anomaly of zonal and annual means since $9.5 \mathrm{kyr} \mathrm{BP}$ as a 50 -year running mean. Anomalies are derived by subtracting the average over the first 20 years from the annual mean values.

ative anomalies of -1 to $-3 \mathrm{Wm}^{-2}$ start to evolve also at northern high latitudes, and are -3 to $-5 \mathrm{Wm}^{-2}$ at the southern high latitudes around $60^{\circ} \mathrm{S}$, whereas SWR anomalies become positive at low latitudes $\left(1\right.$ to $\left.3 \mathrm{Wm}^{-2}\right)$. At around $60^{\circ} \mathrm{N}$, there is a shift from negative to positive anomalies at around $6.8 \mathrm{kyr}$ BP. During the late Holocene, the positive anomalies at the low latitudes intensify $\left(3\right.$ to $\left.5 \mathrm{Wm}^{-2}\right)$, whereas the high-latitude anomalies remain about constant.

\subsubsection{KCM experiments (KCM-CTL, KCM-HOLx10 and KCM-HOL)}

The basis for the KCM experiments is a 1000 -year KCM experiment with $9.5 \mathrm{kyr} \mathrm{BP}$ orbital parameters, $286.6 \mathrm{ppm}$ $\mathrm{CO}_{2}, 805 \mathrm{ppb} \mathrm{CH}_{4}$, and $276 \mathrm{ppb} \mathrm{N}_{2} \mathrm{O}$ concentration (with a final global average SST of $15.8^{\circ} \mathrm{C}$ ), followed by a spinup for a further 1000 years with $9.5 \mathrm{kyr} \mathrm{BP}$ orbital and $9.5 \mathrm{kyr} \mathrm{BP}$ GHG forcing $\left(~ p \mathrm{CO}_{2}=263.8 \mathrm{ppm}, \mathrm{CH}_{4}=678.8\right.$, and $\mathrm{N}_{2} \mathrm{O}=260.6 \mathrm{ppb}$ ). From this state the KCM-CTL and KCM-HOL experiments were started. The KCM control experiment (KCM-CTL) was integrated for a further 8700 years with orbital parameters and atmospheric greenhouse gases kept constant at $9.5 \mathrm{kyr} \mathrm{BP}$ values as a continuation of the spin-up experiment. Due to computational limitations, it was not possible to run KCM-CTL for the full 9500 years. In transient experiments KCM-HOLx10
(950 years) and KCM-HOL (9500 years), time-varying orbital parameters and greenhouse gases as described in Sect. 2.2.1 were applied as forcing.

\subsubsection{Spin-up of PISCES and control experiment (BGC-CTL)}

To spin up the biogeochemical model, monthly mean ocean model output from experiment KCM-CTL was used as forcing. This then available 2000-year long forcing (first 2000 years of KCM-CTL) was repeated three times to spin up PISCES for 6000 years, after which period the model drift as defined by air-sea carbon flux and age of water masses was negligible. It was in particular the age tracer in the deep North Pacific that required the long spin-up time. Note that this BGC spin-up simulation does not achieve a "classical" time-invariant steady state but reflects the internal variability of the first 2000 years from experiment KCM-CTL and any remaining drift. After repeating the KCM-CTL forcing three times for the spin-up, PISCES was integrated for a further 8700 years with the available KCM-CTL forcing as a control experiment for the marine biogeochemistry (BGC-CTL).

\subsubsection{Transient experiments with PISCES (BGC-HOLx10, BGC-HOL)}

Similarly to the set-up of the Holocene KCM experiments, we performed two transient experiments with PISCES in offline mode. Both transient experiments are also started from year 6000 of the PISCES spin-up experiment. In the accelerated experiment BGC-HOLx10, oceanic fields of KCM-HOLx10 and the same atmospheric $p \mathrm{CO}_{2}$ as in KCM-HOLX10 are prescribed as forcing. In this experiment, PISCES is integrated for 950 years corresponding to the period $9.5 \mathrm{kyr} \mathrm{BP}$ to $0 \mathrm{kyr}$, with 10 -fold accelerated forcing. Monthly mean output is stored. The non-accelerated experiment BGC-HOL is integrated for 9500 years forced by the non-accelerated experiment KCM-HOL and the corresponding $p \mathrm{CO}_{2}$. All experiments and their names are summarized in Table 1.

Note that the approach here differs from earlier work to investigate Holocene OMZ changes with a KCM/PISCES model set-up, where PISCES was forced by PMIP-protocol time-averaged oceanic conditions for specific time slices (6 and $0 \mathrm{kyr} \mathrm{BP}, \mathrm{Xu}$ et al., 2015). Also, now all BGC experiments make use of the direct KCM-NEMO output, as opposed to the set-up in Xu et al. (2015), where KCMderived anomalies were added to mean ocean fields from a reanalysis-forced ocean-only set-up.

\subsection{Processing of model output}

All plots in the results section are based on model output interpolated to a regular $1^{\circ} \times 1^{\circ}$ grid using the CDO/SCRIP interpolation package. The only exception is the meridional overturning circulation (MOC) that has been computed on 
Table 1. Experiment names and characteristics. See also Fig. 1 for the temporal evolution of atmospheric greenhouse gases. Lower entries in column "forcing exp" indicate the KCM experiments that have been used to force the BGC experiments. $(\times 10)$ indicates an acceleration factor of $10 . \mathrm{CH}_{4}$ and $\mathrm{N}_{2} \mathrm{O}$ are not prescribed in PISCES.

\begin{tabular}{lrrrrrr}
\hline Experiment & Model & $\begin{array}{r}\text { orbit (kyr BP) } \\
\text { (forcing exp) }\end{array}$ & $p \mathrm{CO}_{2}(\mathrm{ppm})$ & $p \mathrm{CH}_{4}(\mathrm{ppb})$ & $p \mathrm{~N}_{2} \mathrm{O}(\mathrm{ppb})$ & $\begin{array}{r}\text { model } \\
\text { years }\end{array}$ \\
\hline KCM-CTL & KCM & 9.5 & 263.77 & 677.88 & 260.6 & 8,700 \\
KCM-HOLx10 & KCM & $9.5-0(\times 10)$ & $263.77-286.2$ & $575-805$ & $258-268$ & 950 \\
KCM-HOL & KCM & $9.5-0$ & $263.77-286.2$ & $575-805$ & $258-268$ & 9500 \\
\hline BGC-CTL & PISCES & KCM-CTL & 263.77 & n/a & n/a & 8,700 \\
BGC-HOLx10 & PISCES & KCM-HOLx10 & $263.77-286.2$ & n/a & n/a & 950 \\
BGC-HOL & PISCES & KCM-HOL & $263.77-286.2$ & n/a & n/a & 9,500 \\
\hline
\end{tabular}

n/a: not applicable

the original ORCA2 grid for different ocean basins using the standard cdf tool available from the NEMO package (https://github.com/meom-group/CDFTOOLS; last access: 22 May 2018). Maximum values have been computed using the Ferret @ max function.

For all time series the time axis represents the forcing years. This corresponds to model years for the nonaccelerated experiments but not for the accelerated experiments, so any variation caused by long-term internal variability of the model would be spread out in time in the accelerated experiment compared to the non-accelerated experiment. For all time series, the long-term changes are indicated by the fourth-order polynomial fits from the Grace software package (http://plasma-gate.weizmann.ac.il/Grace/; last access: 22 May 2018). An exception is alkalinity, where polynomial fits are of the eighth order to allow for the higher curvature of the time series. Dots represent annual averages and their spread indicates interannual to centennial timescale variability. Plots for BGC-HOL and BGC-CTL are based on output from every tenth year, both to be consistent with BGCHOLx10 and to keep the output file size at a manageable level.

\section{Results}

\subsection{Climate variations over the Holocene}

Since the biogeochemical variations depend to a large extent on the changes in ocean physics, we will first examine the relevant aspects of the simulated climate variations over the Holocene.

\subsubsection{Sea surface temperature}

As a first indicator of simulated changes in ocean physics, we present time series of the global and annual mean SST (Fig. 2a). The global mean SST in KCM-HOL is $15.1^{\circ} \mathrm{C}$ at $9.5 \mathrm{kyr} \mathrm{BP}$, decreases to $14.8^{\circ} \mathrm{C}$ at $6.5 \mathrm{kyr} \mathrm{BP}$, and increases to $15.6^{\circ} \mathrm{C}$ at $0 \mathrm{kyr} \mathrm{BP}$ (based on fourth-order polynomial
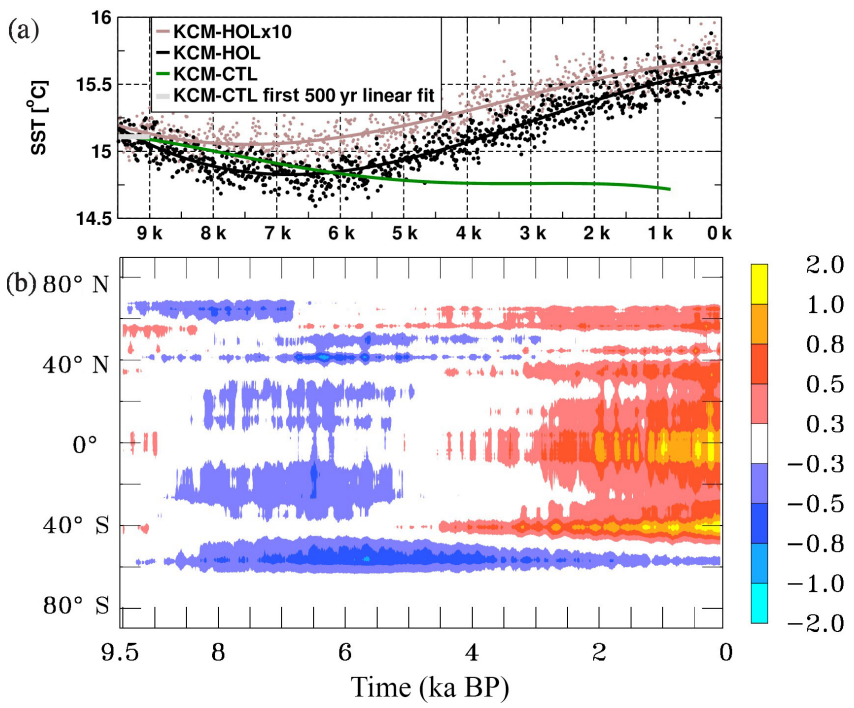

Figure 2. (a) Time series of annual and global mean SST in ${ }^{\circ} \mathrm{C}$ for the three KCM experiments KCM-HOL (non-accelerated forcing, black), KCM-HOLx10 (10 times accelerated forcing, brown), and control experiment KCM-CTL (green). Circles represent annual averages (not every year shown), solid lines a fourth-order polynomial fit. The bold grey line indicates a linear fit over the first 500 years of experiment KCM-CTL. (b) Hovmöller diagram of the zonal mean SST anomaly in ${ }^{\circ} \mathrm{C}$ for $\mathrm{KCM}-\mathrm{HOL}$, computed by subtracting the average over the first 20 years of KCM-HOL from annual mean values and smoothed by a 10 -year running mean. See the colour bar for contour intervals.

fits). In KCM-HOLx10, the temporal evolution is similar to that in KCM-HOL, but with a smaller decrease in global mean SST in the early Holocene (to $15.0^{\circ} \mathrm{C}$ ) and a slightly higher SST than KCM-HOL at the end of the late Holocene $\left(15.7^{\circ} \mathrm{C}\right)$.

Also, the KCM-CTL control experiment displays a decrease in global mean SST of about $0.1{ }^{\circ} \mathrm{C}$ per 1000 years over its first 3500-year integration time. This drift reduces to $0.1{ }^{\circ} \mathrm{C}$ per 2000 years between $6 \mathrm{kyr}$ and $4 \mathrm{kyr} \mathrm{BP}$, and af- 


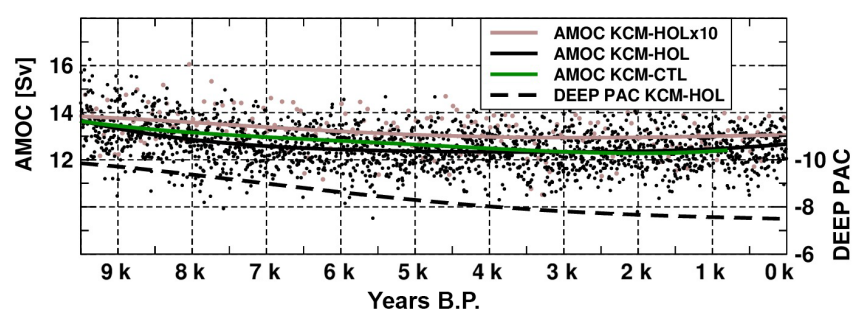

Figure 3. As in Fig. 2a but for the maximum meridional overturning circulation in the Atlantic at $30^{\circ} \mathrm{N}$ (solid lines, left axis) and for the deep Pacific between $3000 \mathrm{~m}$ and $5000 \mathrm{~m}$ depth at $0^{\circ} \mathrm{N}$ (dashed line, right axis) in $\mathrm{Sv}\left(10^{6} \mathrm{~m}^{3} \mathrm{~s}^{-1}\right)$.

ter $4 \mathrm{kyr}$ BP the drift becomes very small. Note that the drift over the first 500 years is negligible in KCM-CTL (grey bar in Fig. 2a). That even a 500-year period of stable SST does not guarantee a later drift-free climate in the control simulation is rather unexpected.

The SST evolution in KCM-CTL implies that the simulated early Holocene decrease in SST in KCM-HOL and KCM-HOLx10 is the combined result of a remaining model drift, and the orbital and $\mathrm{CO}_{2}$ forcing. The initial SST decrease would be weaker, and the SST increase from the midto-late Holocene would be stronger in a drift-free experiment KCM-HOL.

A Hovmöller diagram of zonal mean SST anomalies of KCM-HOL (Fig. 2b) reveals that the mid-Holocene cooling is strongest at the higher latitudes of the Southern Hemisphere (up to $-0.75^{\circ} \mathrm{C}$, centred at around $60^{\circ} \mathrm{S}$ ), whereas the late Holocene warming is strongest between $40^{\circ} \mathrm{S}$ and $40^{\circ} \mathrm{N}$, with maxima around the Equator and at $40^{\circ} \mathrm{S}$. This pattern coincides to a large extent with that of the anomalies of SWR at the ocean and sea-ice surface (Fig. 1b).

The seasonal cycle of global mean SST in KCM-HOL doubles its amplitude from around $0.35^{\circ} \mathrm{C}$ in the early Holocene to $0.7^{\circ} \mathrm{C}$ at about $3 \mathrm{kyr} \mathrm{BP}$ (Fig. A3a in the Appendix), indicating the dominance of the increasing seasonal cycle in the solar forcing on the Southern Hemisphere midlatitudes over the decreasing seasonal cycle on the Northern Hemisphere (Jin et al., 2014). The seasonal cycle of global mean SST remains in the range of slightly less than $0.7^{\circ} \mathrm{C}$ during the late Holocene after $3 \mathrm{kyr}$ BP.

\subsubsection{Meridional overturning circulation}

The Atlantic meridional overturning circulation (AMOC) serves as an indicator of the intensity of deep water formation in the source region of the global conveyor belt. From the NEMO-package output, maximum AMOC at $30^{\circ} \mathrm{N}$ has been computed (Fig. 3). Based on the fourth-order polynomial fits shown in Fig. 3, the simulated maximum AMOC at $30^{\circ} \mathrm{N}$ in $\mathrm{KCM}-\mathrm{HOL}$ at $9.5 \mathrm{kyr} \mathrm{BP}$ is around $13.9 \mathrm{~Sv}$. AMOC gradually decreases to slightly more than $12.5 \mathrm{~Sv}$ until $3 \mathrm{kyr} \mathrm{BP}$, indicating a weak slowdown of the global conveyor belt cir- (a)

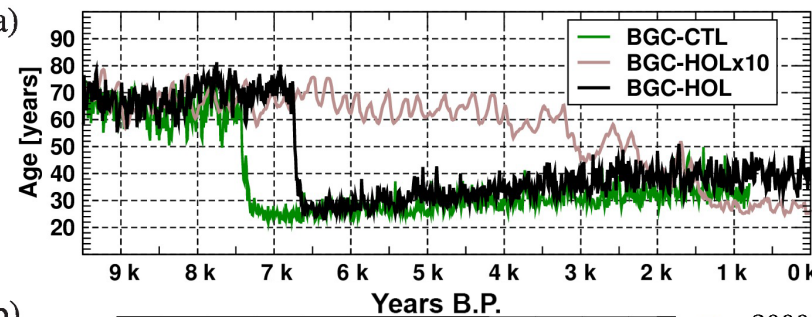

(b)

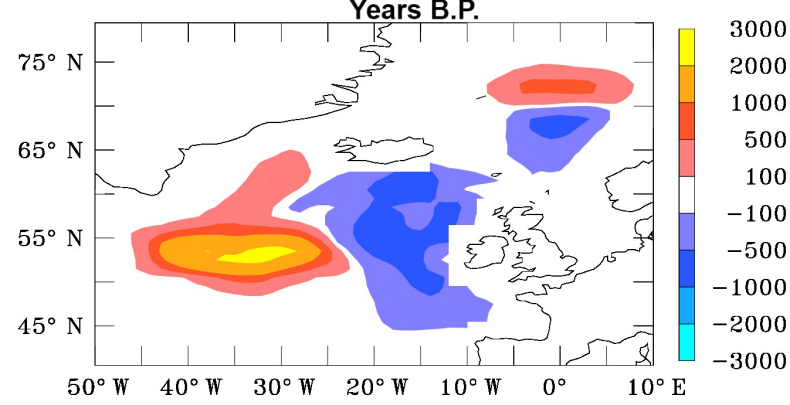

Figure 4. (a) Idealized age (time since contact with the surface) in years averaged over a volume in the deep North Atlantic $\left(40^{\circ} \mathrm{W}-\right.$ $10^{\circ} \mathrm{E}, 40-60^{\circ} \mathrm{N}, 1800-2500 \mathrm{~m}$ depth) based on annual mean values for KCM-HOL (black), KCM-HOLx10 (brown) and KCM-CTL (green). (b) Change in annual maximum mixed layer depth in metres in the North Atlantic between two periods before and after the shift in water mass age in KCM-HOL (7.8 minus $5.8 \mathrm{kyr}$ BP, mean over 200 years centred around the respective dates).

culation. AMOC then marginally increases until the end of the Holocene to around 12.6 Sv (Fig. 3).

In KCM-HOLx10 the mean AMOC and its temporal evolution are similar to KCM-HOL, with a slightly higher mean value. The KCM-CTL control experiment, however, also displays changes in AMOC, similar to the changes in KCMHOL. Overall, the long-term changes in AMOC are relatively small in all experiments and remain within the range of interannual to centennial variations of around $2-3 \mathrm{~Sv}$.

In the Pacific, the deep northward flow that forms the far end of the deep branch of the conveyor belt circulation also weakens with time during the Holocene. Between 3000 and $5000 \mathrm{~m}$ depth, at latitude $0^{\circ} \mathrm{N}$, the decrease in the maximum flow is from almost $10 \mathrm{~Sv}$ at $9.5 \mathrm{kyr} \mathrm{BP}$ to $7.5 \mathrm{~Sv}$ at $0 \mathrm{kyr} \mathrm{BP}$ (dashed line in Fig. 3), indicating a reduced replenishment with younger waters in the deep Pacific. Also, in the Indian Ocean the deep inflow from the south is slightly decreasing with time, but less strongly (not shown).

\subsubsection{Age of water masses}

In addition to AMOC, the age of water masses can serve as an indicator of deep water formation and the intensity of the global deep water circulation, and help to understand changes in oxygen concentration. We will investigate time series of the water mass age in the deep ocean at the source and end regions of the global conveyor belt circulation, namely the North Atlantic and the North Pacific. 


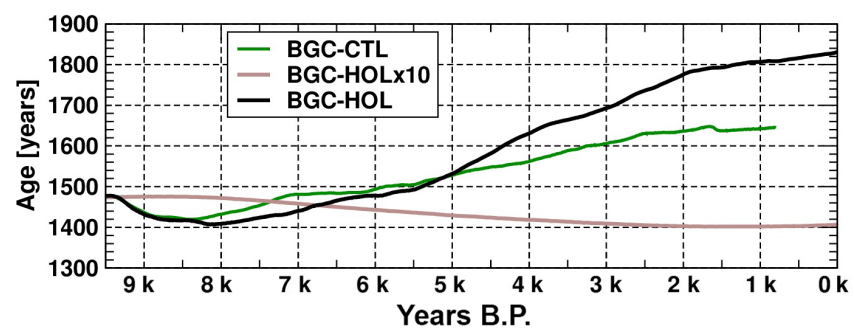

Figure 5. As Fig. 4a, but for the idealized age in years averaged over a volume in the deep North Pacific $\left(150^{\circ} \mathrm{E}-130^{\circ} \mathrm{W}, 40-60^{\circ} \mathrm{N}\right.$, 2500-3500 m depth).

The renewal of water masses in the North Atlantic is indicated by a time series of the age tracer averaged between 1800 and $2500 \mathrm{~m}$ depth and 40 to $10^{\circ} \mathrm{W}, 40$ to $60^{\circ} \mathrm{N}$ in Fig. 4a. The average water mass age in this volume in BGC-HOL initially ranges from 60 to 80 years over the first 2800 years, followed by a sudden decrease to slightly more than 25 years that occurs within a few years around $6.8 \mathrm{kyr} \mathrm{BP}$. This is followed by a gradual increase to around 40 years over the remaining 6800 years of the Holocene. The sudden decrease is likely driven by changes in SST in the North Atlantic which in turn are a consequence of the changing solar radiation in this area. We will come back to this point in Sect. 4.3.

Also, the BGC-CTL control experiment, however, simulates a sudden decrease in water mass age similar to the one in BGC-HOL but occurring at a different time. In the BGCHOLx10 (brown curve in Fig. 4a) accelerated experiment a slightly weaker decrease in age from 60 to 30 years is simulated for the deep North Atlantic, but it occurs over a longer time period (roughly 300 model years) and later in terms of forcing years (between $4 \mathrm{kyr}$ and $1 \mathrm{kyr} \mathrm{BP}$ ).

At the far end of the conveyor belt circulation, the deep North Pacific, changes occur less suddenly than in the North Atlantic, but with a larger amplitude. Between 2500 and $3500 \mathrm{~m}$ depth, $150^{\circ} \mathrm{E}$ to $130^{\circ} \mathrm{W}, 40$ to $60^{\circ} \mathrm{N}$, the water masses show an initial age of 1475 years for all experiments (Fig. 5). In BGC-HOL, water mass age initially decreases to around 1400 years around $7.5 \mathrm{kyr} \mathrm{BP}$, but from then on there is a steady increase up to an age of 1800 years at the end of the Holocene. Also, in BGC-CTL the water mass age in the deep North Pacific increases after $8.5 \mathrm{kyr}$ BP, but less strongly than in KCM-HOL. At $0.8 \mathrm{kyr} \mathrm{BP}$, the end of BGC-CTL, the water mass age is 1650 years compared to 1800 years in KCM-HOL.

This cannot be simulated in the accelerated experiment BGC-HOLx10, however, which runs for 950 years only. In BGC-HOLx 10 deep North Pacific water mass age decreases to 1400 years at $0 \mathrm{kyr} \mathrm{BP}$. The increase in water mass age in the non-accelerated experiment BGC-HOL indicates a considerable slowdown of the global conveyor belt circulation over the Holocene, with significant impact on the marine bio- (a)

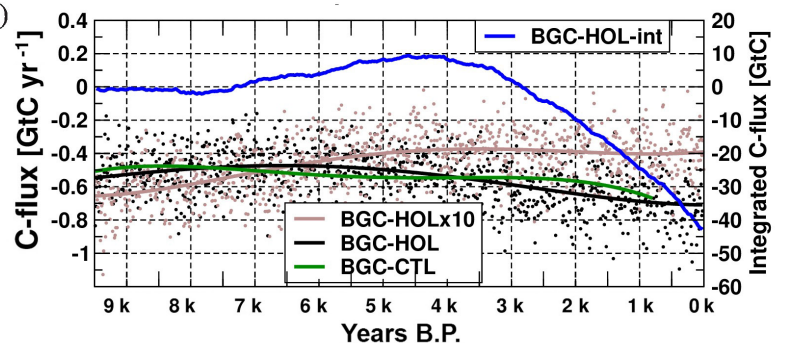

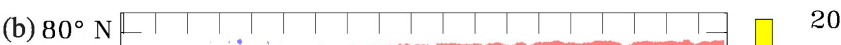

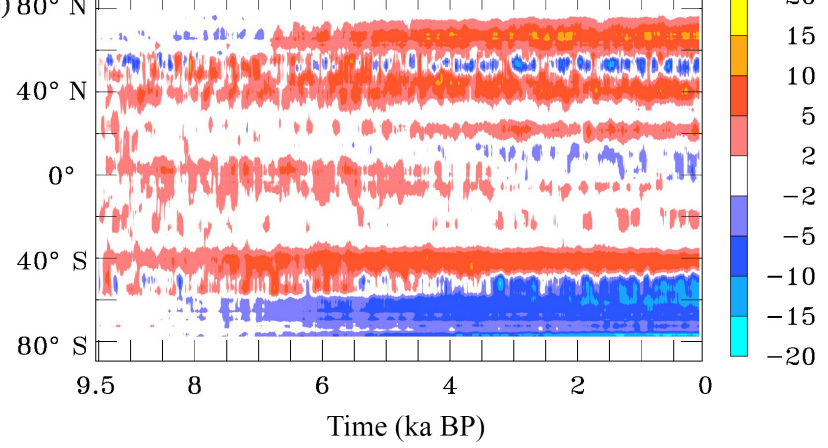

Figure 6. As Fig. 2 but (a) for the global atmosphere-ocean carbon flux $\left(\mathrm{GtC} \mathrm{yr}^{-1}\right)$ of experiments BGC-HOL (black), BGCHOLx10 (brown), and BGC-CTL (green), and the integrated atmosphere-ocean carbon flux for BGC-HOL (GtC, blue). Negative values indicate oceanic outgassing. The net outgassing of around $0.5 \mathrm{GtC} \mathrm{yr}^{-1}$ balances the river input of carbon. (b) Hovmöller diagram of the zonal mean atmosphere-ocean carbon flux change $\left(\mathrm{mol} \mathrm{C} \mathrm{m}{ }^{-2} \mathrm{~s}^{-1}\right.$ ) of experiment BGC-HOL.

geochemistry in the Pacific. We will come back to the age of water masses when investigating the evolution of the EEP OMZ in Sect. 3.2.5.

\subsection{Biogeochemical variations}

\subsubsection{Atmosphere-ocean carbon flux}

In this section the atmosphere-ocean carbon flux is diagnosed. As atmospheric $p \mathrm{CO}_{2}$ is prescribed in all $\mathrm{BGC}$ experiments, the diagnosed flux is a combination of the climatedriven oceanic variations, and the prescribed $p \mathrm{CO}_{2}$. We will come back to this point in the discussion (Sect. 4.5).

In the early Holocene the atmosphere-ocean carbon flux in BGC-HOL is around $-0.5 \mathrm{GtC}_{\text {year }}{ }^{-1}$ (Fig. 6a), the equilibrium value in the PISCES model, indicating an outgassing that balances riverine carbon input. In the mid-Holocene the carbon flux is slightly reduced to around $-0.4 \mathrm{GtC} \mathrm{yr}^{-1}$. Indicating slightly stronger outgassing, the value increases to $-0.75 \mathrm{GtC} \mathrm{yr}^{-1}$ in the late Holocene in experiment BGC$\mathrm{HOL}$, whereas the flux remains at around $-0.4 \mathrm{GtC} \mathrm{yr}^{-1}$ in experiment BGC-HOLx10. In BGC-CTL, the $\mathrm{CO}_{2}$ flux varies between -0.45 and $-0.65 \mathrm{GtC} \mathrm{yr}^{-1}$. The amplitude of the seasonal cycle of the atmosphere-ocean carbon flux 
(a)
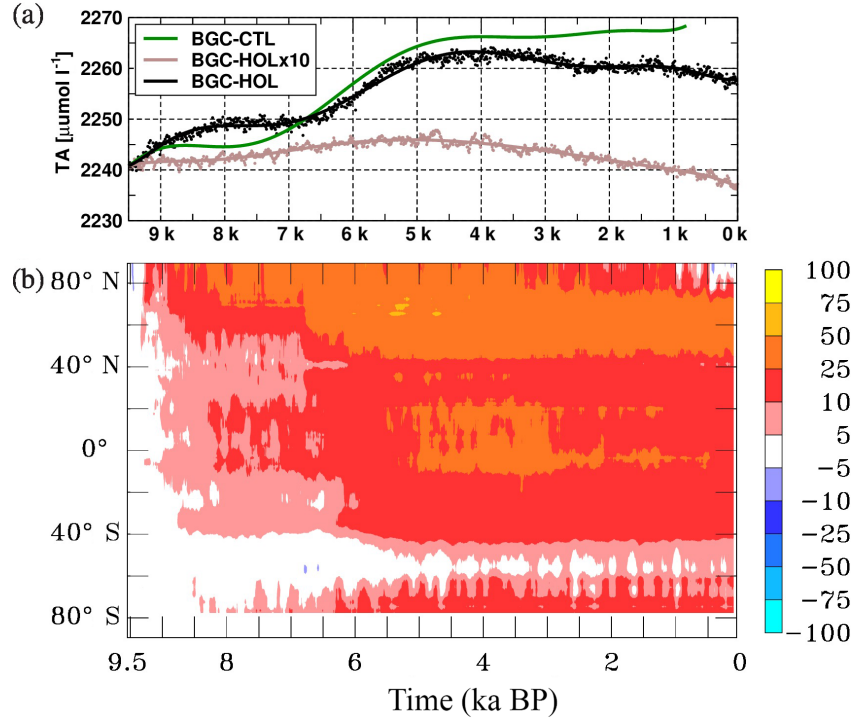

Figure 7. As Fig. 2, but for (a) time series of global mean total alkalinity (TA) at the surface in $\mu \mathrm{mol} \mathrm{L}{ }^{-1}$ as eighth-order polynomial fit, and (b) Hovmöller diagram of the changes in zonal and annual mean surface TA in $\mu \mathrm{mol} \mathrm{L}-1$.

in BGC-HOL decreases from early to late Holocene from around 1.8 to only $0.8 \mathrm{GtC} \mathrm{yr}^{-1}$ (Fig. A3b).

The time-integrated atmosphere-ocean carbon flux in BGC-HOL (blue curve in Fig. 6a) is almost zero during the early Holocene, and increases to $10 \mathrm{GtC}$ from 7 to $4.5 \mathrm{kyr} \mathrm{BP}$. From 4 to $0 \mathrm{kyr} \mathrm{BP}$ there is a steady decrease to $-42 \mathrm{GtC}$, indicating a net flux from the ocean to the atmosphere in the late Holocene.

The zonal mean changes in the atmosphere-ocean carbon flux in BGC-HOL (Fig. 6b) indicate a change from net $\mathrm{CO}_{2}$ uptake to outgassing in the high-latitude Southern Ocean and mostly increased uptake at northern mid-latitudes. Also, the positive anomaly around $40^{\circ} \mathrm{S}$ shows stronger uptake from mid-to-late Holocene.

\subsubsection{Surface alkalinity and $\mathrm{pH}$}

In BGC-HOL total alkalinity (TA) at the sea surface increases from 2240 to $2250 \mu \mathrm{mol} \mathrm{L}^{-1}$ until $8 \mathrm{kyr} \mathrm{BP}$ and increases further to $2265 \mu \mathrm{mol} \mathrm{L}^{-1}$ between 6.5 and $4 \mathrm{kyr} \mathrm{BP}$ (Fig. 7a). After $4 \mathrm{kyr} \mathrm{BP}$, TA decreases to $2258 \mu \mathrm{mol} \mathrm{L}^{-1}$ in the late Holocene. In experiment BGC-HOLx10 the global mean concentration of TA remains in the range of 2240 to $2245 \mu \mathrm{mol} \mathrm{L}^{-1}$, with a maximum at around $6 \mathrm{kyr}$ BP. Surprisingly, also in BGC-CTL TA increases considerably and even slightly more strongly than in BGC-HOL.

The increase in TA in BGC-HOL occurs over most latitudes (Fig. 7b), with a stronger increase north of $40^{\circ} \mathrm{N}$ and around the Equator between 5 and $3 \mathrm{kyr} \mathrm{BP}$, whereas there is only a small trend around $60^{\circ} \mathrm{S}$. This temporal evolution can (a)

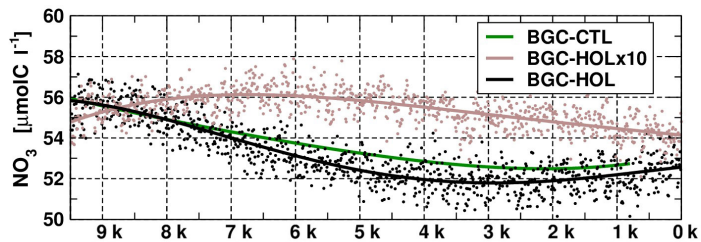

(b) $80^{\circ} \mathrm{N}\|\mathrm{H}\|$ |

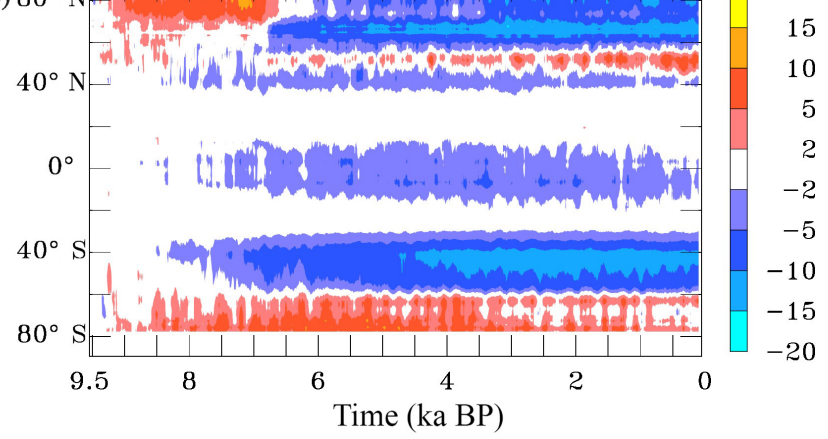

Figure 8. As Fig. 2 but (a) for the average $\mathrm{NO}_{3}$ concentration averaged over the uppermost $100 \mathrm{~m}$ in $\mu \mathrm{mol} \mathrm{C} \mathrm{L}{ }^{-1}$ and (b) Hovmöller diagram of the changes in zonal and annual mean $\mathrm{NO}_{3}$ concentra-

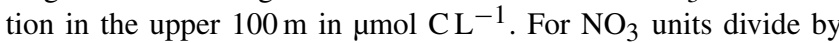
7.6 .

(a)

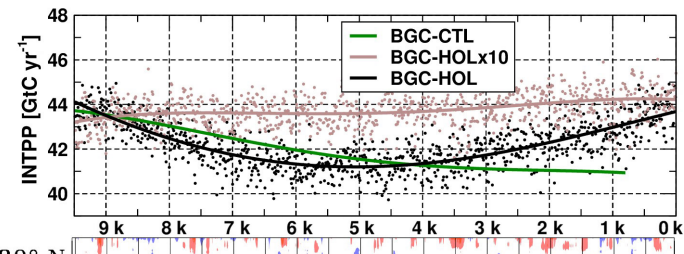

(b) $80^{\circ}$

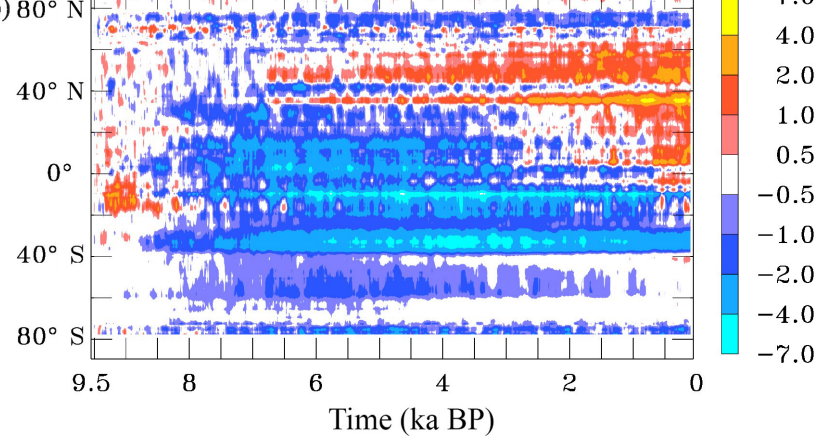

Figure 9. As Fig. 2 but (a) for time series of global primary production integrated over the upper $100 \mathrm{~m}_{\text {in }} \mathrm{GtC} \mathrm{yr}^{-1}$ (INTPP), and (b) Hovmöller diagram of the changes in zonal and annual mean INTPP in mol C m${ }^{-2} \mathrm{~s}^{-1} \times 10^{8}$.

only partly be explained by a reduction in $\mathrm{CaCO}_{3}$ export that would drive an increase in TA (Sect. 3.2.4, Fig. 11b).

The global and annual mean $\mathrm{pH}$ at the surface follows the temporal variations in atmospheric $p \mathrm{CO}_{2}$ and varies only little during the Holocene, with changes in the range of a few hundredths of $\mathrm{pH}$ units (8.13-8.16, not shown). 


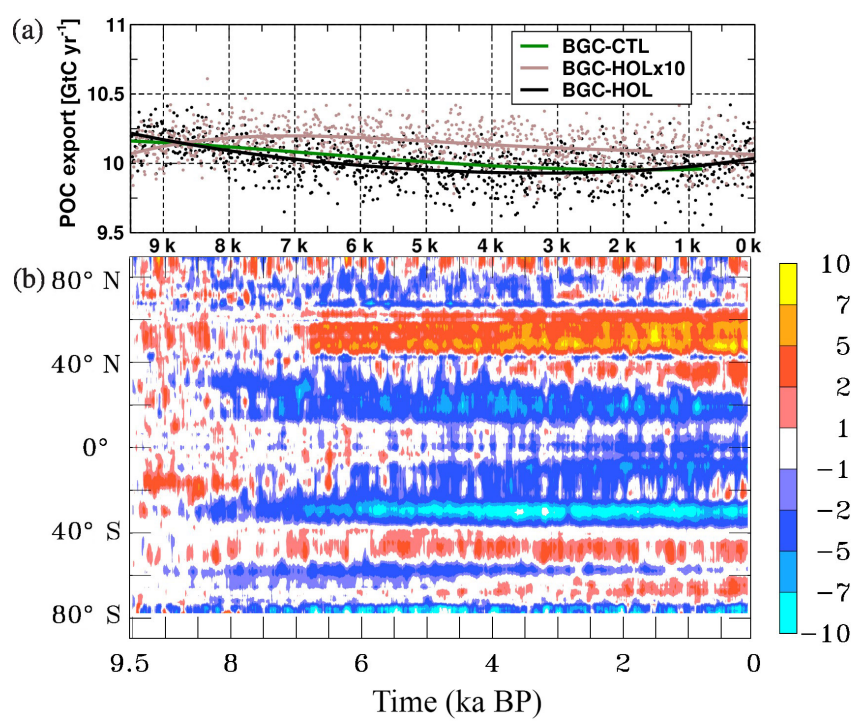

Figure 10. As Fig. 2 but (a) for time series of global export production at the bottom of the euphotic layer in $\mathrm{GtC} \mathrm{yr}^{-1}$, and (b) Hovmöller diagram of the changes in zonal and annual mean global export production in $\mathrm{mol} \mathrm{C} \mathrm{m}^{-2} \mathrm{~s}^{-1} \times 10^{9}$.

\subsubsection{Nutrients}

In BGC-HOL, the global mean $\mathrm{NO}_{3}$ concentration averaged over the euphotic zone $(0-100 \mathrm{~m})$ decreases with time from $56 \mu \mathrm{mol} \mathrm{C} \mathrm{L}{ }^{-1}$ in the early Holocene to $52 \mu \mathrm{molC} \mathrm{L}^{-1}$ around $3 \mathrm{kyr} \mathrm{BP}$. This is followed by a slight increase to almost $53 \mu \mathrm{molCL}^{-1}$ at $0 \mathrm{kyrBP}$ (Fig. 8a). In BGCHOLx 10, the global mean concentration is fairly constant at $56 \mu \mathrm{molC} \mathrm{L}^{-1}$ until $5 \mathrm{kyr} \mathrm{BP}$, and then declines gradually to $54 \mu \mathrm{molC} \mathrm{L}^{-1}$ in the late Holocene. In BGC-CTL, the decrease in the global mean $\mathrm{NO}_{3}$ concentration is similar to that in BGC-HOL until $7 \mathrm{kyr}$ BP, and becomes weaker thereafter.

The Hovmöller diagram of the zonal mean $\mathrm{NO}_{3}$ concentration changes in experiment BGC-HOL (Fig. 8b) reveals that the decrease in the $\mathrm{NO}_{3}$ concentration originates from a large range of latitudes mainly in the Southern Hemisphere (40 to $60^{\circ} \mathrm{S}$ ), and also from high northern latitudes after the "event" around $6.8 \mathrm{kyr} \mathrm{BP}$ in the North Atlantic centred at $60^{\circ} \mathrm{N}$. The weak increase in global mean euphotic-zone $\mathrm{NO}_{3}$ concentration after $3 \mathrm{kyr}$ BP originates mainly from a small band centred at $55^{\circ} \mathrm{N}$, counteracted by a weakening of the negative anomalies around and south of the Equator $\left(10^{\circ} \mathrm{N}\right.$ to $20^{\circ} \mathrm{S}$ ).

\subsubsection{Marine ecosystem}

Here the focus is on the three major components of the marine ecosystem with relevance for the carbon cycle, namely the integrated primary production, the export production, and the calcite (calcium carbonate) export. The primary production integrated over the euphotic zone (INTPP) is a mea-

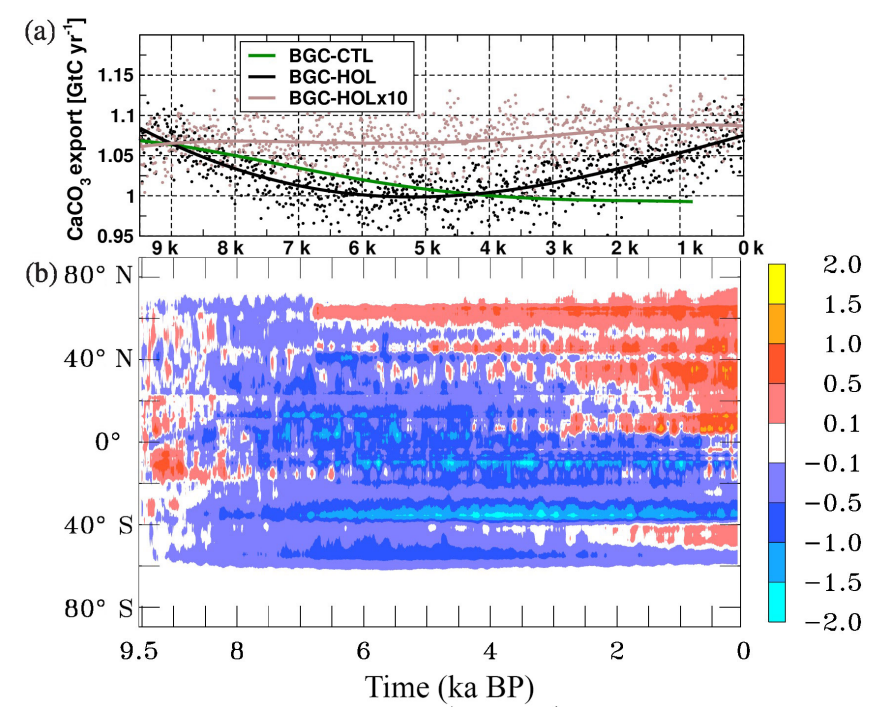

Figure 11. As Fig. 2 but (a) for time series of global $\mathrm{CaCO}_{3}$ export production at the bottom of the euphotic layer in $\mathrm{GtC} \mathrm{yr}^{-1}$, and (b) Hovmöller diagram of change in zonal and annual mean $\mathrm{CaCO}_{3}$ export in $\mathrm{mol} \mathrm{C} \mathrm{m} \mathrm{C}^{-2} \mathrm{~s}^{-1} \times 10^{9}$.

sure of the productivity of the marine ecosystem. INTPP in BGC-HOL is around $44 \mathrm{GtC} \mathrm{yr}^{-1}$ at the beginning of the Holocene, decreasing to a minimum of around $41 \mathrm{GtC} \mathrm{yr}^{-1}$ in the mid-Holocene at $5 \mathrm{kyr} \mathrm{BP}$, and then increasing again to $44 \mathrm{GtC} \mathrm{yr}^{-1}$ towards the late Holocene (Fig. 9a). Interannual variations are about $2-3 \mathrm{GtC} \mathrm{yr}^{-1}$. In the accelerated experiment BGC-HOLx10, INTPP remains fairly constant over the entire Holocene at 43 to $44 \mathrm{GtC} \mathrm{yr}^{-1}$. In the control experiment BGC-CTL INTPP decreases steadily form 44 to around $41 \mathrm{GtC} \mathrm{yr}^{-1}$ at the end of the simulation.

The decrease in global mean INTPP in BGC-HOL originates mainly from latitudes south of $40^{\circ} \mathrm{N}$ and is generally more pronounced in the Southern Hemisphere (Fig. 9b). The increase after $4 \mathrm{kyr}$ BP can be traced back to an increase in INTPP between 40 and $60^{\circ} \mathrm{N}$ beginning around $6 \mathrm{kyr} \mathrm{BP}$ and intensifying and gradually spreading southward for the remainder of the Holocene. This response is likely driven by a combination of the changes in SST, PAR, and nutrient availability (Figs. 2b, 1b, 8b), as there is some similarity between zonal mean anomalies of INTPP and SST, SWR at the sea/sea-ice surface, and $\mathrm{NO}_{3}$, but none of the patterns is matched exactly.

The export production at $100 \mathrm{~m}$ depth in BGC-HOL, here computed as the sum of small and large POC (see Sect. 2.1.2), is around $10.2 \mathrm{GtC} \mathrm{yr}^{-1}$ at $9.5 \mathrm{kyr} \mathrm{BP}$. During the early and mid-Holocene, there is a slight decrease to $9.8 \mathrm{GtC} \mathrm{yr}^{-1}$ at $4 \mathrm{kyr} \mathrm{BP}$, and export production remains fairly constant at that level until $3 \mathrm{kyr} \mathrm{BP}$, after which there is a modest increase to $10 \mathrm{GtC} \mathrm{yr}^{-1}$ (Fig. 10a). The accelerated experiment BGC-HOLx10, after a small increase in the early Holocene, simulates a relatively uniform decrease 


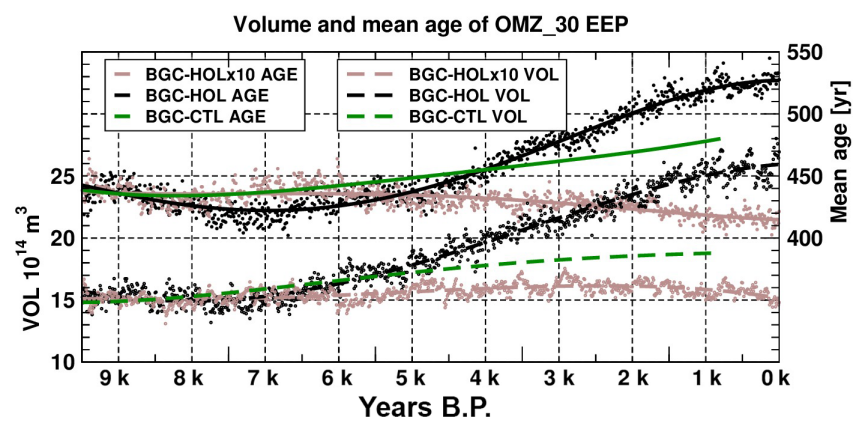

Figure 12. Time series of EEP OMZ volume for a threshold of $30 \mu \mathrm{mol} \mathrm{L}{ }^{-1}$ in $10^{14} \mathrm{~m}^{3}$ (left axis, lower dashed curves) and mean age of water mass in the EEP OMZ in years (right axis, upper solid curves). EEP defined as $140-74^{\circ} \mathrm{W}, 10^{\circ} \mathrm{S}-10^{\circ} \mathrm{N}, 0-1000 \mathrm{~m}$ depth. Circles represent annual mean values of the OMZ volume, and dots are annual mean values of the water mass age in the EEP OMZ for BGC-HOL (black), BGC-HOLx10 (brown), and BGCCTL (green). Solid lines represent polynomial fits of fourth order.

by just $0.1 \mathrm{GtC} \mathrm{yr}^{-1}$ from 8 to $0 \mathrm{kyrBP}$. Also, control experiment BGC-CTL simulates a quite uniform decrease in export production, from $10.2 \mathrm{GtC} \mathrm{yr}^{-1}$ at the beginning to $10.0 \mathrm{GtC} \mathrm{yr}^{-1}$ at the end of the experiment.

The zonal mean export production in BGC-HOL decreases mainly at low latitudes in two bands centred around $20^{\circ} \mathrm{N}$ and $35^{\circ} \mathrm{S}$ (Fig. 10b). An increase occurs mainly between 30 and $60^{\circ} \mathrm{N}$, intensifying after $6.8 \mathrm{kyr} \mathrm{BP}$. The apparent deviations from the pattern of INTPP could be explained by changing temperatures (with an impact on the remineralization rate) and changes in the particle composition (with an impact on settling velocity) and relative contributions from small and large POC to the export production. For slowly sinking small POC, we find a more continuous but minor decline of global export from 3.7 to $3.6 \mathrm{GtC} \mathrm{yr}^{-1}$, whereas for the faster sinking large POC the decline is more rapid during the first 3000 years of the Holocene (from 6.5 to $6.3 \mathrm{GtC} \mathrm{yr}^{-1}$ ) and the export is fairly constant thereafter (not shown).

The temporal evolution of the calcite export in all experiments is similar to that of INTPP: In BGC-HOL, calcite export is around $1.08 \mathrm{GtC} \mathrm{yr}^{-1}$ in the early Holocene (Fig. 11a), followed by a decrease of about $0.1 \mathrm{GtC} \mathrm{yr}^{-1}(10 \%)$ until the mid-Holocene (around $6 \mathrm{kyr} \mathrm{BP}$ ) after which there is a slight increase to $1.05 \mathrm{GtC} \mathrm{yr}^{-1}$ towards the late Holocene. In BGC-HOLx 10 the calcite export fluctuates fairly constantly around its initial value of about $1.08 \mathrm{GtC} \mathrm{yr}^{-1}$ whereas in BGC-CTL an initially stronger decline from $1.075 \mathrm{GtC} \mathrm{yr}^{-1}$ to slightly less than $1 \mathrm{GtC} \mathrm{yr}^{-1}$ at $0.8 \mathrm{kyr} \mathrm{BP}$ is simulated.

The zonal mean changes in $\mathrm{CaCO}_{3}$ export in BGC-HOL are similar to those of INTPP, with an almost global decrease in the early Holocene, and a recovery at the higher northern latitudes after $6.8 \mathrm{kyr} \mathrm{BP}$. The recovery gradually extends to the entire Northern Hemisphere in the late Holocene (Fig. 11b).
Overall the variations of the global marine biological production and export rates remain in the range of about $10 \%$ throughout the Holocene even in the non-accelerated experiment BGC-HOL, with a tendency towards lower values in the mid-Holocene, and variations surprisingly similar in magnitude in the control run.

\subsubsection{Oxygen minimum zones}

The largest OMZ in the global ocean resides in the EEP. The EEP here is defined as the region from $140-74^{\circ} \mathrm{W}$, $10^{\circ} \mathrm{S}-10^{\circ} \mathrm{N}$, and to compute the EEP OMZ volume a threshold of $30 \mu \mathrm{mol} \mathrm{L}^{-1}$ is used. The volume of the EEP OMZ initially remains fairly constant in BGC-HOL from 9.5 to $7 \mathrm{kyr} \mathrm{BP}$ at $15 \times 10^{14} \mathrm{~m}^{3}$ (Fig. 12, left $y$-axis, dashed lines). But from $7 \mathrm{kyr}$ BP onwards, the OMZ volume steadily increases to around $26 \times 10^{14} \mathrm{~m}^{3}$ at $0 \mathrm{kyr} \mathrm{BP}$ in KCM-HOL, an increase of more than $70 \%$. In the accelerated forcing experiment BGC-HOLx10 the EEP OMZ volume remains fairly constant over the entire Holocene. Also, in BGC-CTL the EEP OMZ volume increases after $8 \mathrm{kyr} \mathrm{BP}$, but less strongly than in BGC-HOL.

At the same time as the OMZ volume increases in BGC$\mathrm{HOL}$, the age of the water mass within the OMZ increases from around 440 years $(9.5-7 \mathrm{kyr} \mathrm{BP})$ to 530 years at 0 kyr BP (Fig. 12, right y-axis, solid lines). Note that the accelerated experiment does not show an increase in the OMZ volume and water mass age (Fig. 12). In BGC-HOLx10 the age decreases mainly after $6 \mathrm{kyr}$ BP from 430 to 415 years. The longer control run, however, also shows substantial variations of OMZ volume and water mass age. In BGC-CTL the water mass age increases to 480 years at the end of the experiment, with a slightly stronger increase in the last 2000 years of the experiment.

Time series of the oxygen saturation $\left(\mathrm{O}_{2}\right.$ sat $)$ and apparent oxygen utilization (AOU) between 100 and $800 \mathrm{~m}$ depth in the EEP for BGC-HOL demonstrate a relatively stable $\mathrm{O}_{2}$ sat (following mainly the temperature evolution) but an increase in AOU from 252 to $267 \mu \mathrm{mol} \mathrm{L}^{-1}$ (Fig. 13a). Late Holocene minus early Holocene differences show that $\mathrm{O}_{2}$ sat is decreasing in the upper $400 \mathrm{~m}$ of the EEP by up to $5 \mu \mathrm{mol} \mathrm{L}^{-1}$, but increasing by up to $4 \mu \mathrm{mol} \mathrm{L} \mathrm{L}^{-1}$ below that depth (Fig. 13b, shading). The corresponding temperature change is a warming of up to $0.4^{\circ} \mathrm{C}$ in the $100-400 \mathrm{~m}$ depth range, and a cooling of up to $0.4^{\circ} \mathrm{C}$ below $400 \mathrm{~m}$ depth, with an overall very similar pattern to that of AOU (Fig. 13b, contours).

For AOU, there is a more uniform-with-depth tendency to higher values in the late Holocene, with AOU up to $25 \mu \mathrm{mol} \mathrm{L}{ }^{-1}$ higher at around $1000 \mathrm{~m}$ depth and slightly lower late Holocene AOU values only near the surface (Fig. 13c, shading). The corresponding change in idealized water mass age ranges from 10 to 60 years between 400 and $1000 \mathrm{~m}$, with a similar pattern to the AOU changes (Fig. 13c, contours). 
(a)

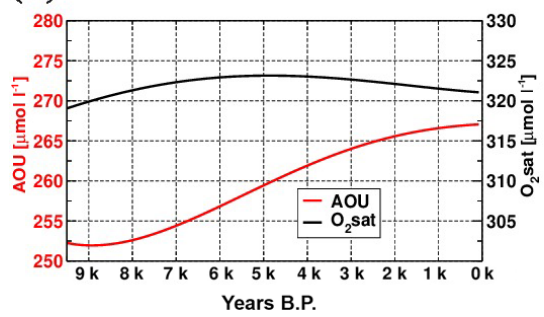

(b) $\Delta \mathrm{O}_{2}$ sat

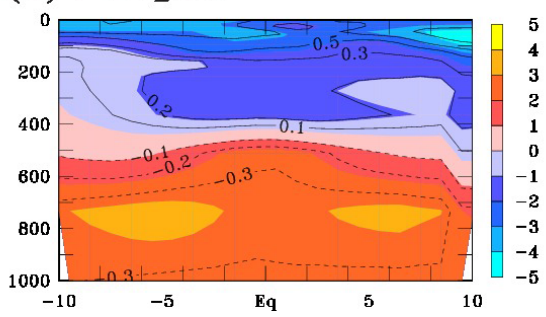

(c) $\triangle \mathrm{AOU}$

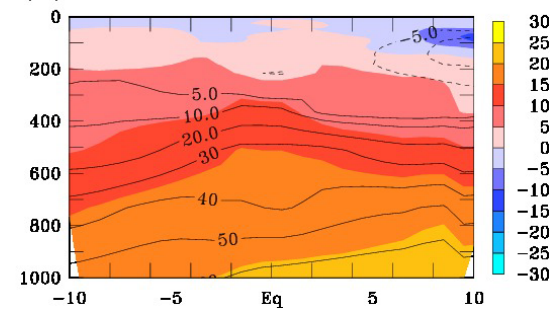

Figure 13. (a) Time series of $\mathrm{AOU}$ and $\mathrm{O}_{2}$ sat in the EEP (region as in Fig. 12, but for 100-800 m depth), and (b, c) meridional sections of zonal mean differences of late Holocene minus early Holocene for (b) $\mathrm{O}_{2}$ sat (shading, $\mu \mathrm{mol} \mathrm{L}^{-1}$ ) and temperature (contours, ${ }^{\circ} \mathrm{C}$ ) and (c) AOU (shading, $\mu \mathrm{mol} \mathrm{L}{ }^{-1}$ ) and water mass age (contours, years). The contour interval for temperature is $0.1^{\circ} \mathrm{C}$ from -0.3 to $0.3^{\circ} \mathrm{C}$, with additional lines for $0.5,0.7$, and $1^{\circ} \mathrm{C}$. The contour interval for water mass age is 10 years from -10 to 60 years, with additional lines at -5 and 5 years. Zero contours are omitted.

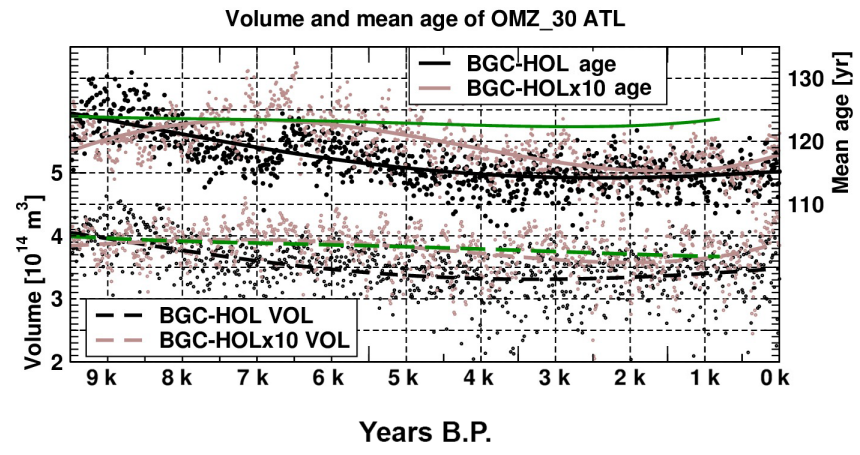

Figure 14. As Fig. 12 but for the Atlantic in the area of $5^{\circ} \mathrm{W}-$ $15^{\circ} \mathrm{E}, 30^{\circ} \mathrm{S}-5^{\circ} \mathrm{N}, 0-1000 \mathrm{~m}$ depth. OMZ volume for a threshold of $30 \mu \mathrm{mol} \mathrm{L}-1$ in $10^{14} \mathrm{~m}^{3}$ and water mass age in years.

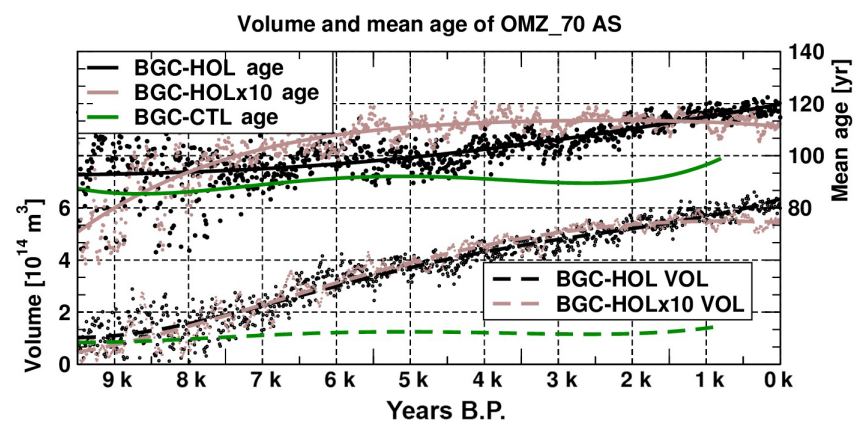

Figure 15. As Fig. 12 but for the Arabian Sea in the area of 55$75^{\circ} \mathrm{E}, 8.5-22^{\circ} \mathrm{N}, 100-800 \mathrm{~m}$ depth. OMZ volume for a threshold of $70 \mu \mathrm{mol} \mathrm{L}^{-1}$ in $10^{14} \mathrm{~m}^{3}$ and water mass age in years.

Export production in the EEP is fairly constant over the Holocene at $0.58 \mathrm{GtCa}^{-1}$ (figure not shown), with only a marginal tendency towards lower values in the late Holocene, and thus can be ruled out as a driver of the expansion of the EEP OMZ. The average $\mathrm{O}_{2}$ concentration within the OMZ decreases slightly from $18.5 \mu \mathrm{mol} \mathrm{L}^{-1}$ at $9.5 \mathrm{kyr} \mathrm{BP}$ to $17.5 \mu \mathrm{mol} \mathrm{L}^{-1}$ at $0 \mathrm{kyrBP}$ in BGC-HOL (not shown).
In contrast to the EEP, for the OMZ in the tropical Atlantic mainly south of the Equator, the changes over the Holocene are more modest and of opposite sign. In the region from $5^{\circ} \mathrm{W}-15^{\circ} \mathrm{E}, 30^{\circ} \mathrm{S}-5^{\circ} \mathrm{N}$, the volume of the $\mathrm{OMZ}$ in BGC-HOL decreases slowly from around $4 \times 10^{14} \mathrm{~m}^{3}$ to $3.5 \times 10^{14} \mathrm{~m}^{3}$, and the average age over the OMZ decreases from about 125 years to 115 years (Fig. 14).

For the Arabian Sea a steady increase in OMZ volume (here computed for a $70 \mu \mathrm{mol} \mathrm{L} \mathrm{L}^{-1}$ threshold) is simulated in BGC-HOL $\left(1 \times 10^{14}\right.$ to $\left.6 \times 10^{14} \mathrm{~m}^{3}\right)$, concurrent with an increase in water mass age from 100 to 120 years (Fig. 15). In the BGC-HOLx10 accelerated experiment, there is a similar increase in OMZ volume, whereas mean water mass age increases mainly before $6 \mathrm{kyr}$ BP. In BGC-CTL average water mass age and $\mathrm{OMZ}$ volume are much less variable than for the transient experiments. Note that the results for the Arabian Sea in Gaye et al. (2017) are from an earlier accelerated experiment, started at year 1500 of KCM-CTL. The earlier results are quite similar but not identical to BGC-HOLx10.

\section{Discussion}

\subsection{Holocene SST variations}

Comparing the KCM-simulated temporal evolution of global mean SST with observation-based estimates and other model simulations, there is a notable difference between models and observations. During the proxy-derived climate optimum in the mid-Holocene ( $8 \mathrm{kyr}$ to $5 \mathrm{kyr} \mathrm{BP}$ ) observation-based global mean temperature is about $0.4{ }^{\circ} \mathrm{C}$ warmer than $1961-$ 1990 (Marcott et al., 2013), and borehole temperatures from Greenland are about $2{ }^{\circ} \mathrm{C}$ warmer (Dahl-Jensen et al., 1998). During the same period the KCM-simulated SST is at its lowest value, about $0.8^{\circ} \mathrm{C}$ colder than at the end of the simulation at $0 \mathrm{kyr} \mathrm{BP}$ in the non-accelerated experiment (Fig. 2a).

The largest fraction of the initial post-glacial temperature increase in the reconstructions of Marcott et al. (2013), however, occurs in the very early Holocene (11.3 to $9 \mathrm{kyr} \mathrm{BP})$, 
whereas the simulations discussed here start at $9.5 \mathrm{kyr}$ BP to avoid difficulties with the simulation of retreating ice masses and increasing sea level. Simulations, therefore, start at a time when continental ice sheets and sea level are assumed to be close to present-day values. This very early Holocene temperature increase can, therefore, not be simulated by KCM in its present configuration. We note that in the Holocene time-slice experiments with KCM, the annual mean SST is also lowest for the $6 \mathrm{kyr}$ BP experiment and highest for the 0 kyr BP experiment (e.g. Schneider et al., 2010, Fig. 6).

In support to our model results, and raising the general question of how representative the mainly land based proxy-derived temperature anomalies can be transferred to the Holocene SST, Varma et al. (2016) find a similar temporal evolution of global mean SST in their orbitally forced Community Climate System Model version3 simulations of the Last and Present Interglacials (LIG and PIG, respectively) mainly in their non-accelerated PIG experiment (their Fig. 4). The larger amplitude of our simulated temperature change can be explained by the small cooling trend still inherent in the control run (KCM-CTL, about $0.1{ }^{\circ} \mathrm{C} / 1000$ years, an otherwise very acceptable value) and the additional forcing from the transient $\mathrm{CO}_{2}$ and $\mathrm{CH}_{4}$ variations in $\mathrm{KCM}-\mathrm{HOL}$ and KCM-HOLx10 with a range of about $20 \mathrm{ppm}$ for $\mathrm{CO}_{2}$, and of about $100 \mathrm{ppb}$ for $\mathrm{CH}_{4}$ (Fig. 1a), whereas Varma et al. (2016) used constant $p \mathrm{CO}_{2}$ values during their simulations.

From earlier experiments with KCM with/without a $1 \% / 2 \%$ p.a. atmospheric $p \mathrm{CH}_{4}$ increase a contribution on the order of $0.1{ }^{\circ} \mathrm{C}$ to the simulated Holocene global mean SST variation from the prescribed $\mathrm{CH}_{4}$ seems a reasonably conservative estimate (Biastoch et al., 2011, supplementary material Fig. S3). We also performed an additional transient non-accelerated KCM experiment with constant $p \mathrm{CO}_{2}$ of $286.4 \mathrm{ppm}$ but orbital forcing for the Holocene that has not been discussed here. In that experiment, the global mean SST fluctuates within a constant range almost until $4 \mathrm{kyr} \mathrm{BP}$, i.e. with no mid-Holocene cooling, and increases by 0.2 to $0.3^{\circ} \mathrm{C}$ from 4 to $0 \mathrm{kyr} \mathrm{BP}$. This indicates that the early to mid-Holocene SST evolution in KCM-HOL is a result of the GHG forcing and any remaining model drift, whereas for the late Holocene both GHG and orbital forcing drive an increase in SST.

We note that also in the simulations of Varma et al. (2016) seemingly small variations in atmospheric $p \mathrm{CO}_{2}$ lead to larger variations in the simulated global mean SST than expected from climate sensitivity estimates: For their PIG and LIG simulations with atmospheric $p \mathrm{CO}_{2}$ of $280 \mathrm{ppm}$ and $272 \mathrm{ppm}$, respectively, the initial global mean SST difference is more than $0.35^{\circ} \mathrm{C}$. This sensitivity is of similar magnitude as the $0.6^{\circ} \mathrm{C}$ for $\mathrm{KCM}$ control simulations with a $p \mathrm{CO}_{2}$ of 286.4 and $263 \mathrm{ppm}$.

As such, the Holocene simulations of Varma et al. (2016) and the LGM-to-present simulations discussed in Liu et al. (2014) support the results of our simulations as technically sound. The discrepancy between simulated SST, and proxy- based estimates, however, raises the question of why the simulations result in such a different temporal evolution than observation-based temperature reconstructions.

Possibly there might be a difference in the behaviour of the SST and the mainly land-based temperature reconstructions. For example, Renssen et al. (2009) display simulated differences between 9 and $0 \mathrm{kyr}$ BP, and their Fig. 3c suggests mainly colder temperatures of the Northern Hemisphere oceans for $9 \mathrm{kyr} \mathrm{BP}$, whereas the trend is the opposite for the land surface mainly in Eurasia. Leduc et al. (2010) investigate $\mathrm{Mg} / \mathrm{Ca}$ ratios and alkenone unsaturation values $\left(U_{37}^{K^{\prime}}\right)$ for a range of sediment cores from different locations. In their study, the majority of the $\mathrm{U}_{37}^{K^{\prime}}$ records suggest a Holocene warming trend in the EEP and the tropical Atlantic, whereas $\mathrm{Mg} / \mathrm{Ca}$ records indicate a Holocene cooling trend in the same regions. For the North Atlantic, the alkenone-derived SST decreases over the Holocene, but $\mathrm{Mg} / \mathrm{Ca}$-derived SST shows a differing warming/cooling trend for the various records. Apparently, further research is needed on this issue.

The model-data mismatch could also imply that at least early Holocene temperature variations were determined not only by orbital forcing or greenhouse gases, but also by solar and volcanic forcing, ice sheets, and internal variability of the system (see also Wanner et al., 2008; Renssen et al., 2009, for a more complete and regional investigation of driving mechanisms of Holocene climate). However, including total solar irradiance (TSI) in the forcing would likely not solve the problem. Reconstructed TSI variations over the Holocene are around $1 \mathrm{~W} \mathrm{~m}^{-2}$ (Vieira et al., 2011), and assuming a climate sensitivity of $0.5 \mathrm{~K}\left(\mathrm{~W} \mathrm{~m}^{-2}\right)^{-1}$ (IPCC, 2007), these could translate into global mean temperature variations of a similar magnitude to that simulated here, but reconstructed TSI is relatively low during the mid-Holocene.

As proxies might be seasonally biased (e.g. Schneider et al., 2010), we also analysed the northern summer (JuneJuly-August, JJA) and northern winter (December-JanuaryFebruary, DJF) SST separately, but did not find a better match with the proxy-derived mid-Holocene warming. Also, using the yearly maximum temperature, indicating local summer, does not change the temporal behaviour; it only shifts the SST curve upward by roughly $2 \mathrm{~K}$. In summary, the simulated large-scale SST evolution in $\mathrm{KCM}-\mathrm{HOL}$ is seemingly not very sensitive to the choice of season. The Holocene climate conundrum (Liu et al., 2014) is still not solved.

\subsection{Holocene circulation changes}

The meridional overturning in the Atlantic in KCM-HOL decreases over the Holocene by about $1.5 \mathrm{~Sv} / 10 \%$, whereas the deep inflow into the Pacific decreases by $2.5 \mathrm{~Sv} / 20 \%$ (Sect. 3.1.2, Fig. 3). As the slowdown of the circulation in the deep Pacific in experiment KCM-HOL seems stronger than one would expect from the decrease in the AMOC, this sug- 
gests a decoupling of the North Atlantic and the North Pacific over the course of the Holocene simulations. This indicates that changes in the "far-end" conveyor belt circulation are not necessarily represented by changes in AMOC.

Blaschek et al. (2015) describe a set of Holocene experiments including various forcings with the Earth system model of intermediate complexity LOVECLIM and compare their results with available proxies for AMOC, including those investigated by Hoogakker et al. (2011); see Table 2 in Blaschek et al. (2015). Since the temporal evolution of AMOC in our experiment KCM-HOL is similar to that of experiment OG (Orbital and Greenhouse gases as forcing) in Blaschek et al. (2015), we can assume that their findings are also valid for our experiments: additional forcing with the $8.2 \mathrm{kyr}$ BP freshwater pulse and also ice-sheet topography changes seem to be required to simulate the weak early Holocene AMOC derived from proxies. As those forcings are not included in our model experiment, there is a further reason to discuss our experiments as a sensitivity experiment to orbital and GHG forcing. Also, Renssen et al. (2005) find in their experiments with a coupled intermediate complexity model that AMOC remains fairly constant throughout their 9000-year Holocene experiment, despite the changes in location of the deep water formation regions.

\subsection{North Atlantic}

Our original intention in examining the North Atlantic more closely was to investigate whether the changes in the OMZs could be traced back to the deep water source regions. It turned out, however, that significant changes occurred in the North Atlantic that justify further analysis. In Sect. 3.1.3 we showed a sudden drop in the water mass age in the deep North Atlantic (Fig. 4a) that can be traced back to a westward shift in the deep water formation areas south of Iceland, and a northward shift north of Iceland, as indicated by the difference in the annual maximum of the mixed layer depth in the North Atlantic (Fig. 4b). In addition to the shift in location, also an increase in the mixed layer depth of up to $3000 \mathrm{~m}$ occurs in the more southwestern part of the Nordic Seas. This is accompanied by a change in SST at $60^{\circ} \mathrm{N}$ around $6.8 \mathrm{kyr} \mathrm{BP}$ from negative to positive anomalies (Fig. $2 \mathrm{~b}$ ) and an increase in export production (Fig. 10b).

An SST time series at $53^{\circ} \mathrm{N}, 30^{\circ} \mathrm{W}$ shows a rapid decrease in SST, a time series at $62^{\circ} \mathrm{N} 30^{\circ} \mathrm{W}$ a slight SST increase, and both time series have reduced variability after $7 \mathrm{kyr} \mathrm{BP}$ (figure not shown). Figure $1 \mathrm{~b}$ reveals a shift from negative anomalies of annual mean SWR at the ocean/sea-ice surface just north of $60^{\circ} \mathrm{N}$ to positive anomalies in a narrow band south of $60^{\circ} \mathrm{N}$, and a negative anomaly north of $75^{\circ} \mathrm{N}$. In particular the positive anomaly south of $60^{\circ} \mathrm{N}$ seems surprising, as TOA radiation in the North Atlantic is decreasing from 9.5 to $7 \mathrm{kyr} \mathrm{BP}$ from around 190 to $180 \mathrm{~W} \mathrm{~m}^{-2}$. This decrease is more pronounced in summer, with a potential for preconditioning the water masses for winter convec- tion, whereas winter insolation is very low anyway, so any changes would be of limited impact. The TOA SWR Northern Hemisphere decrease is fairly linear and continues further for the entire Holocene. The abrupt response of KCM to the forcing anomalies suggests that there may be a critical threshold for a sudden shift of deep water formation areas in the (model) North Atlantic during the Holocene.

This shift is also visible in the concentration of $\mathrm{NO}_{3}$ (Fig. 8b) and the marine ecosystem as indicated by INTPP, and export production that both increase south of $60^{\circ} \mathrm{N}$ after $6.8 \mathrm{kyr} \mathrm{BP}$ and decrease north of $65^{\circ} \mathrm{N}$ (Figs. 9b, 10b).

As also the control simulation shows a sudden shift in deep North Atlantic water mass age, this indicates that small variations in the range of the internal (model) variability are sufficient to trigger shifts in the pattern of North Atlantic deep mixing.

\subsection{Holocene OMZ variations}

The dominant mechanisms for past and future OMZ variability have yet to be established (Jaccard and Galbraith, 2012; Bopp et al., 2017). Potential processes are changes in export production, setting the amount of detritus that can be remineralized, temperature changes that affect oxygen solubility and organic matter remineralization, and changes in circulation. Circulation changes are changing the time during which oxygen can be consumed in subsurface waters due to remineralization of organic matter, and the rates at which deoxygenated water masses can be replenished.

For example, Deutsch et al. (2011) analyse an ocean general circulation model forced by atmospheric reanalyses from 1959 to 2005 to identify the main mechanism for oxygen minimum zone variability in the more recent past. From the analyses the authors find that downward shifts of the thermocline and hence an uplifting of the Martin curve (Martin et al., 1987) drive an increase in the suboxic volume due to higher respiration rates at the same water depth. Accordingly, upward shifts of the thermocline cause decreasing suboxic volume.

On glacial to interglacial timescales, on/off changes in the AMOC have been identified as driving OMZ variations also in the Pacific (Schmittner et al., 2007). In their model experiments with the UVic (University of Victoria) intermediate complexity model, however, the AMOC collapses entirely, whereas the AMOC in our Holocene simulations varies only by around $10 \%$. As such we find no indication of a direct connection between AMOC changes and the EEP OMZ for more modest changes in AMOC.

Bopp et al. (2017) suggest a compensation of temperaturedriven changes in $\mathrm{O}_{2}$ saturation and ventilation-driven changes in AOU to explain past and future $\mathrm{O}_{2}$ trends. In addition to the variations in idealized water mass age that can serve as an indicator of ventilation, we also computed the fields of $\mathrm{O}_{2}$ saturation and AOU for experiment BGC-HOL. While $\mathrm{O}_{2}$ saturation in the EEP has a similar temporal evo- 
lution to SST, AOU reflects the general slowdown of the circulation in the Pacific (see Fig. 13a). Meridional sections in the EEP reveal a different Holocene trend of $\mathrm{O}_{2}$ saturation in the upper and lower parts of the OMZ: a decrease in the upper part, and an increase below $400 \mathrm{~m}$, reflecting the temporal evolution of temperature. AOU resembles water mass age changes, and is stronger in the late Holocene at all depths, with the exception of a small decrease in the upper $100 \mathrm{~m}$ off the Equator.

Thus, the long-term changes show a decoupling of oxygen saturation and AOU, the former driven by temperature changes, the latter by a slower circulation (increase in water mass age). We note that this differs from the compensation of $\mathrm{O}_{2}$ saturation and AOU changes shown in Bopp et al. (2017), who investigate shorter simulations of much stronger climate variations, such as for present day to future, LGM to mid-Holocene, and the shorter timescale fluctuations from the piControl simulations. In these simulations, a decrease in $\mathrm{O}_{2}$ saturation has a signature in lower AOU and vice versa. However, also Bopp et al. (2017, Fig. 4b) find a correlation between AOU and idealized water mass age for the LGM to mid-Holocene changes, and question whether the compensating effect also holds for longer multi-century simulations. The results shown here indicate that for millennial timescales the $\mathrm{O}_{2}$ saturation and AOU changes may be decoupled.

In summary, the dominating mechanism for OMZ changes in our transient, non-accelerated Holocene experiment is a slowdown of the circulation that develops over thousands of years. This slowdown is not mainly from changes in AMOC, but is more confined to the deep Pacific. It results in widespread oxygen consumption and an increase in $\mathrm{AOU}$ with an effect on the EEP OMZ (Fig. 12) where the deep waters are upwelled. In the Atlantic, circulation changes remain small over the Holocene, and the OMZ volume remains fairly constant in the Atlantic OMZ (Fig. 14).

In contrast to studies based on global warming and $\mathrm{O}_{2}$ (Cocco et al., 2013; Bopp et al., 2013) and marine biological production (Steinacher et al., 2010) that showed an impact of stratification changes on $\mathrm{O}_{2}$ fields and marine biological production, here we simulate much smaller temperature variations. The global and annual mean of the MLD in KCM-HOL reveals little temporal variability: MLD is around $48 \mathrm{~m}$ at $9.5 \mathrm{kyr} \mathrm{BP}$, and starts to decrease after $5.5 \mathrm{kyr} \mathrm{BP}$ to around $47 \mathrm{~m}$ at $0 \mathrm{kyr} \mathrm{BP}$. We, therefore, state that stratification changes play only a minor role in largescale $\mathrm{O}_{2}$ changes during the Holocene.

A modest deoxygenation of the global ocean has been observed over the last 50 years $(-2 \%$ globally, Schmidtko et al., 2017). Moreover, a further decline of the oxygen content, and hence an extension of the world's OMZs, has been projected in ocean and Earth system model simulations of the next century as a consequence of global warming (Matear and Hirst, 2003; Cocco et al., 2013; Bopp et al., 2013). As the non-accelerated experiment BGC-HOL yields an expanding OMZ in the EEP during the late Holocene, and in gen- eral declining oxygen concentrations as a result of the natural forcing only, this raises the question of whether the presently observed deoxygenation might also partly be caused by the continuation of an externally forced trend. This would not have to be in contradiction with an anthropogenic contribution to the observed oxygen decline, but could also point to an amplification of the externally forced trend by the effects of anthropogenic warming as both mechanisms point in the same direction, albeit with different timescales.

Comparing our results with the proxy-derived estimates of OMZ intensity in the eastern tropical South Pacific (Salvatteci et al., 2016), we find an indication of stronger denitrification towards the late Holocene in the proxy data. This would likely support our result of an expanding EEP OMZ, but the proxies could also have recorded a more local decrease in $\mathrm{O}_{2}$ concentration, rather than a general expansion of the OMZ. Moreover, the proxy data for the early Holocene show a decrease in $\delta^{15} \mathrm{~N}$, indicating increasing oxygen concentrations, which is, however, not simulated by our model.

An earlier version of the accelerated experiment BGCHOLx10 was compared to sediment core based estimates of Holocene OMZ evolution in the Arabian Sea. Based on $\delta^{15} \mathrm{~N}$ records, Gaye et al. (2017) find that the AS OMZ has intensified since the last LGM, and that most of this increase occurred throughout the Holocene (their Fig. 6), which is in agreement with the model results presented here. In summary, however, as we do not simulate nitrogen isotopes (or other proxies), a direct comparison between proxies and model results is somewhat limited. A more comprehensive comparison of proxy data and our model results has been planned for the future.

\subsection{Atmosphere-ocean $\mathrm{CO}_{2}$ fluxes}

Concerning the observed changes in atmospheric $p \mathrm{CO}_{2}$ over the Holocene, Indermühle et al. (1999) postulate that changes in the terrestrial biosphere and SST were driving the observed changes. Elsig et al. (2009) base their investigation on $\delta^{13} \mathrm{C}$ measurements from an Antarctic ice core. They attribute the $5 \mathrm{ppm}$ early Holocene decrease in atmospheric $p \mathrm{CO}_{2}$ to an uptake of the land biosphere, and the mid-tolate Holocene increase of $20 \mathrm{ppm}$ to changes in the oceans carbonate chemistry. Coral reef formation on newly flooded shelfs (Vecsei and Berger, 2004) has been identified as a possible source of atmospheric $\mathrm{CO}_{2}$ in the early Holocene. A comprehensive EMIC-based investigation of interglacial carbon cycle dynamics and potential mechanisms that drive atmospheric $\mathrm{CO}_{2}$ changes during these periods can be found in Brovkin et al. (2016).

Here we can also use our model results to some limited extent to investigate for our model system if and how the ocean may have contributed to the observed atmospheric $p \mathrm{CO}_{2}$ variations. Limitations arise from that the $\mathrm{BGC}$ experiments are forced with observed $p \mathrm{CO}_{2}$, and don't include coral reefs nor calcium carbonate compensation from sed- 
iments. Potential mechanisms in our model come from the three "carbon pumps" of the ocean, i.e. changes in oceanic temperature and circulation (physical pump), alkalinity (alkalinity counter pump), and biological production and export of organic matter resulting in changes in the strength (Six and Maier-Reimer, 1996; Ducklow et al., 2001; Segschneider and Bendtsen, 2013) and the efficiency (Sarmiento and Gruber, 2006) of the biological pump.

During the early Holocene the integrated carbon flux is constant (Fig. 6a), despite a decrease in atmospheric $\mathrm{CO}_{2}$ (Fig. 1a): during this initial phase, the global mean SST in $\mathrm{KCM}-\mathrm{HOL}$ is decreasing by about $0.3^{\circ} \mathrm{C}$ (Fig. 2), and the alkalinity in BGC-HOL is increasing by $10 \mu \mathrm{mol} \mathrm{L}{ }^{-1}$ (Fig. 7a), while export production is slightly decreasing by $0.2 \mathrm{GtC} \mathrm{yr}^{-1}$ (Fig. 10a). In summary, these effects balance out during the early Holocene, and the time-integrated atmosphere-ocean carbon flux remains about zero until 7 kyr BP (Fig. 6a, blue curve).

In the mid-Holocene, from 7 to $4 \mathrm{kyrBP}$, the timeintegrated carbon flux is slowly increasing to a total ocean uptake of $10 \mathrm{GtC}$. This occurs during a period of atmospheric $p \mathrm{CO}_{2}$ increase that would drive oceanic uptake, but SST is rising slowly, export production is further decreasing, and alkalinity is increasing by a further $10 \mu \mathrm{mol} \mathrm{L}^{-1}$.

In the late Holocene, after $4 \mathrm{kyr} \mathrm{BP}$, the ocean is outgassing a total of $50 \mathrm{GtC}$, potentially driven by the simulated increase in SST and damped by the increasing prescribed atmospheric $p \mathrm{CO}_{2}$.

The general slowdown of the circulation over the Holocene suggests a weakening of the physical pump, and a strengthened biological pump as more dissolved inorganic carbon (DIC) from remineralization of organic matter is stored in the deep ocean. Finally, as a result of reduced calcite export, simulated global mean surface alkalinity increases mainly during the mid-Holocene (6.5 kyr to $5 \mathrm{kyr} \mathrm{BP}$ ), which would lead to decreasing $p \mathrm{CO}_{2}$ in surface waters and hence a sink for carbon in the atmosphere.

To investigate whether the efficiency of the biological pump ( $E_{\mathrm{BP}}$, Sarmiento and Gruber, 2006, Eq. 4.1.1) changed over the Holocene we computed $E_{\mathrm{BP}}$ from the global mean $\mathrm{NO}_{3}$ concentrations from $0-100 \mathrm{~m}$ depth (surface) and 100$200 \mathrm{~m}$ depth (deep), as suggested by Sarmiento and Gruber (2006, Fig. 4.1.7). It was found that there is little variation of $E_{\mathrm{BP}}$ over the Holocene, with values for $E_{\mathrm{BP}}$ of around $0.47 \pm 0.01$ and a marginal tendency for increased efficiency in the late Holocene (an increase from 0.468 to 0.473 based on a fourth-order polynomial fit), i.e. opposite to the simulated atmosphere-ocean flux that indicates stronger outgassing in the late Holocene.

In summary, the contribution of oceanic processes to airsea carbon fluxes is in line with the prescribed $p \mathrm{CO}_{2}$ in the mid-Holocene, while reversing the flux expected from the atmospheric forcing in the early and late Holocene.

\subsection{Non-accelerated, accelerated, and time-slice experiments}

Finally we discuss the gain from the transient experiments performed here compared to the earlier time-slice climate model experiments at 9.5, 6, and $0 \mathrm{kyr} \mathrm{BP}$ with $\mathrm{KCM}$ (Schneider et al., 2010) and also the biogeochemistry experiments with PISCES (Xu et al., 2015). Note that the experiments in Schneider et al. (2010) were also performed with preindustrial $p \mathrm{CO}_{2}(286.4 \mathrm{ppm})$ and hence neglect the forcing from changing atmospheric $p \mathrm{CO}_{2}$ that is included here.

One obvious gain from the transient experiments is the more complete time coverage over the Holocene, potentially allowing better comparison with proxies and providing more continuous information. The transient experiments can also be used to determine whether the timing of the time-slice experiments is appropriate. For the physical fields like global mean SST (Fig. 2a) we find that the time-slice experiments fit well with the extrema of the transient experiment. As the state of the biogeochemistry but also of AMOC in the early and late Holocene are not much different, time-slice experiments of these periods would miss any changes in between.

Also, the time-slice experiments including a 6 kyr BP simulation do not capture the extrema of the simulated time series of the transient experiments BGC-HOL and BGCHOLx10. For example, the integrated primary production and export of detritus have their lowest values at $5 \mathrm{kyr}$ to 4 kyr BP (Figs. 9a, 10a). In particular, the evolution of the EEP OMZ in the non-accelerated experiment BGC-HOL was not captured in the earlier time-slice experiments of $\mathrm{Xu}$ et al. (2015), even though they also showed smaller mid-Holocene $\mathrm{OMZs}$ caused by changes in the equatorial current system.

So, are non-accelerated experiments generally required, or can the same knowledge be obtained from experiments with accelerated astronomical forcing? This has already been investigated for physical models (Varma et al., 2016) where a good agreement for physical variables has been found between accelerated and non-accelerated transient simulations over the Holocene at low latitudes, but deviations were found at high latitudes and in the deep ocean. When comparing our results for the accelerated and non-accelerated experiments, we find that also the global mean SST shows some deviations, but it is mainly for the biogeochemical system (that was not included in the Varma et al. (2016) model) that large deviations are simulated. This is mainly the case for globally averaged fields. More regionally, in the EEP OMZ there is a large discrepancy between accelerated and non-accelerated experiment $\mathrm{OMZ}$ volume, whereas results are similar for the Arabian Sea OMZ.

\section{Conclusions}

In this study, a 9500-year simulation of Holocene climate and marine biogeochemistry is analysed together with a 10-fold 
accelerated simulation and - to our knowledge for the first time - a control run of similar length to the non-accelerated experiment. The simulated climate in terms of global mean SST is characterized by a mid-Holocene cooling, and a late Holocene warming following the temporal evolution of the greenhouse gas forcing and the short-wave radiation at the sea surface. This is in contradiction to a proxy-derived midHolocene climate optimum and a late-Holocene cooling. The open question why KCM and other ocean-atmosphere coupled climate models do not simulate the proxy-derived Holocene climate evolution under astronomical and GHG forcing remains a major issue. As long as this issue is not resolved, we have to regard the biogeochemistry simulation as a sensitivity study to orbital and greenhouse gas forcing of the climate system.

Most of the characteristic variables of the marine carbon cycle, like global atmosphere-ocean $\mathrm{CO}_{2}$ flux, primary and export production, and global mean surface $\mathrm{pH}$, display changes of up to $10 \%$ during the Holocene in the nonaccelerated experiment. Variations are generally smaller in the accelerated experiment, but for some variables the control experiment also displays variations of similar magnitude to those of the non-accelerated experiment. This - surprisingly large - variability in the control experiment is a combination of a small remaining model drift, but mainly the internal variability of the climate and marine biogeochemistry system. This internal variability is of a similar magnitude to the - orbitally and greenhouse gas - forced variability during the Holocene. An exception is the EEP OMZ volume that increases by more than $50 \%$ in the second half of the Holocene in the non-accelerated experiment, but not in the accelerated experiment, and is much weaker in the control run. This increase in OMZ volume can be attributed to a weakening deep northward inflow into the Pacific, and a corresponding widespread increase in water mass age and AOU that develops over thousands of years. In summary, the simulations demonstrate the necessity of performing transient simulations with non-accelerated forcing when examining the marine biogeochemistry changes over the Holocene, but also of control runs of similar length.

Data availability. Data are available from the corresponding author by request. A subset of the data used for plotting and a set of figures with the completed control run (when available) will be made available at: https://nextcloud.ifg.uni-kiel.de/remote.php/ webdav/BG-2017-554-data/bg-2017-554-data.tar. 


\section{Appendix A: Simulated and observed oxygen concentrations}

Figure A1 shows simulated and observation-based (Garcia et al., 2013) $\mathrm{O}_{2}$-concentration profiles in the three major oxygen minimum zones (OMZ) in the world ocean. For all areas, the simulated oxygen concentrations at the surface are overestimated due to the cold bias in KCM-simulated SST compared to present-day estimates of observed SST (Locarini et al., 2013). The near-surface oxygen gradient (upper $200 \mathrm{~m}$ ) is simulated well in the EEP and the Arabian Sea (AS), but overestimated in the tropical South Atlantic (SATL). Between 200 and $1000 \mathrm{~m}$, the observed concentrations are matched well in the SATL, and do not differ too much in the EEP, whereas the observations are poorly matched in the AS, mainly due to a lack of faster sinking large detritus in this area. In general, all BGC simulations show a tendency towards overly high $\mathrm{O}_{2}$ concentrations in the upper water column, and overly low concentrations below $1000 \mathrm{~m}$, with the exception of the AS. Overall, the representation of oxygen minimum zones is within the range of large-scale global ocean biogeochemistry models, which all have their errors (Cabré et al., 2015).
As the threshold for the definition of an OMZ is not very well defined in the literature, we display the OMZ volume for a range of threshold values for observations and as simulated in Fig. A2 for a) the global ocean and b) the EEP. For thresholds up to $70 \mu \mathrm{mol} \mathrm{L}^{-1}$, the simulated OMZ volume is generally too low for the upper $1000 \mathrm{~m}$, while the best match is at a threshold of $80 \mu \mathrm{mol} \mathrm{L}^{-1}$ for the global ocean and at $70 \mu \mathrm{mol} \mathrm{L}^{-1}$ for the EEP 0-5000 m range. For higher thresholds, the model simulations overestimate the OMZ volume.
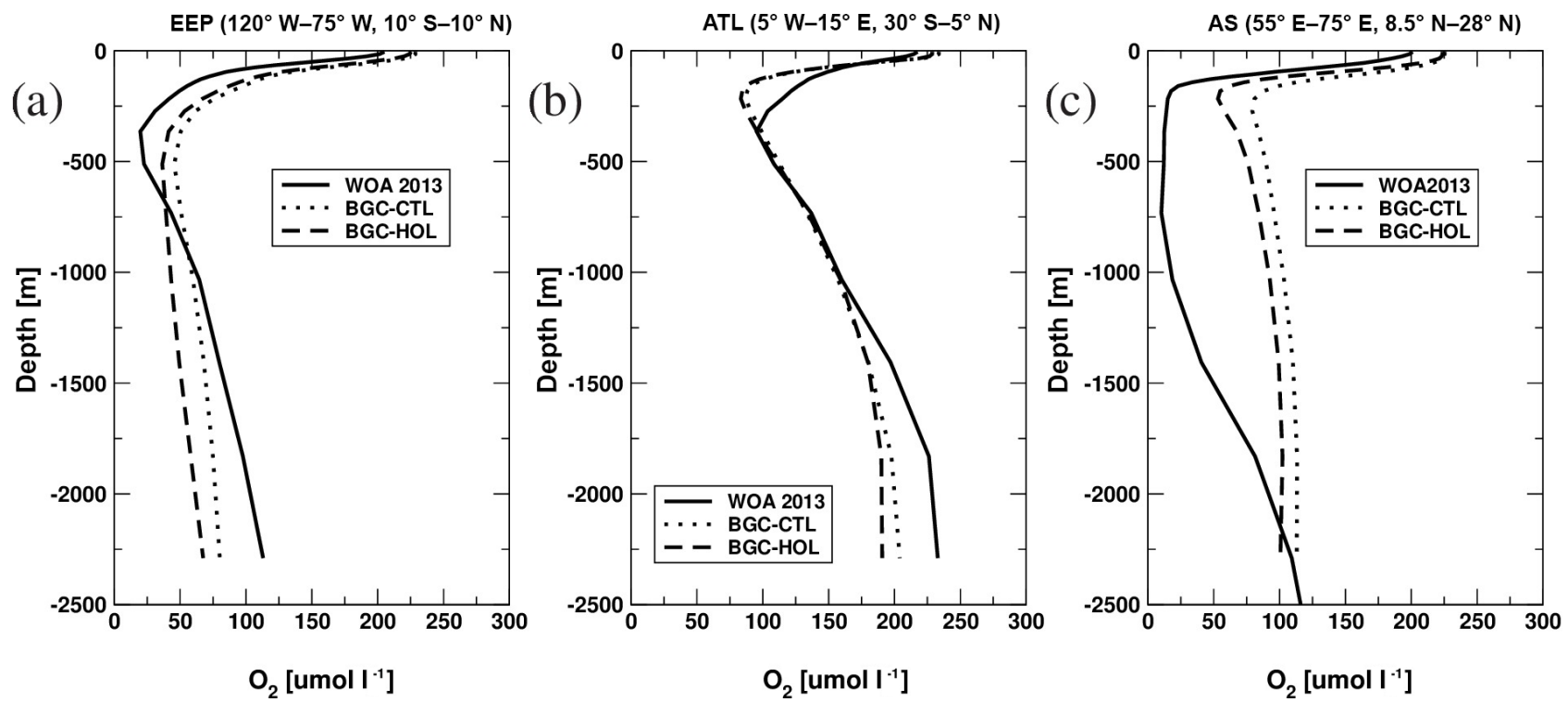

Figure A1. Simulated and observation-based profiles of average $\mathrm{O}_{2}$ concentration in $\mu \mathrm{mol} \mathrm{L}{ }^{-1}$ in the three major oxygen minimum zones in the world ocean for (a) the EEP, (b) the tropical South Atlantic, and (c) the Arabian Sea. Based on observations (WOA2013, Garcia et al., 2013, solid), and from experiments BGC-CTL (dotted) and BGC-HOL (dashed) averaged over the last 200 years. 

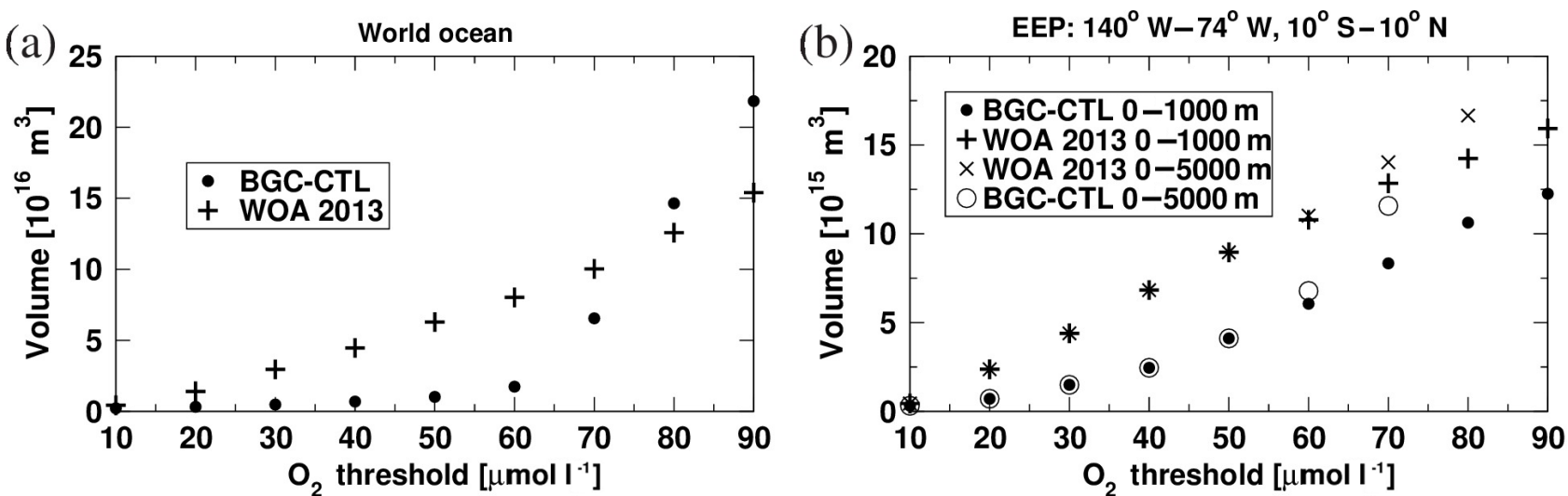

Figure A2. Simulated and observation-based (WOA2013, Garcia et al., 2013) volume of water masses with oxygen concentration below the threshold value indicated on the $x$-axis for (a) the world ocean from the surface to the seafloor in $10^{15} \mathrm{~m}^{3}$, and (b) the EEP for $0-1000$ and $0-5000 \mathrm{~m}$ in $10^{14} \mathrm{~m}^{3}$. See legends for explanations of symbols.

(a)

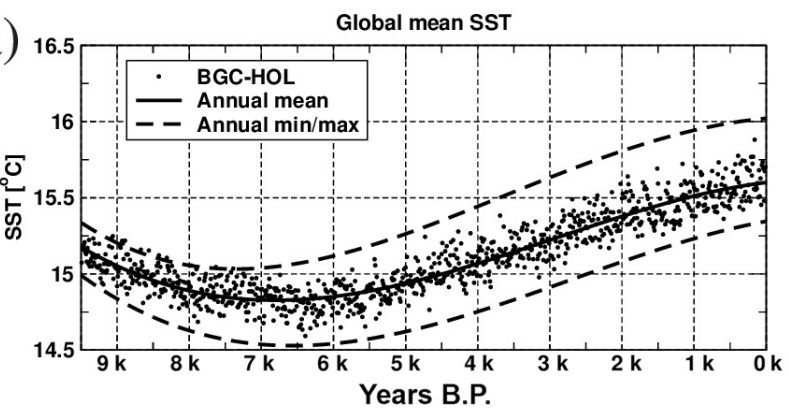

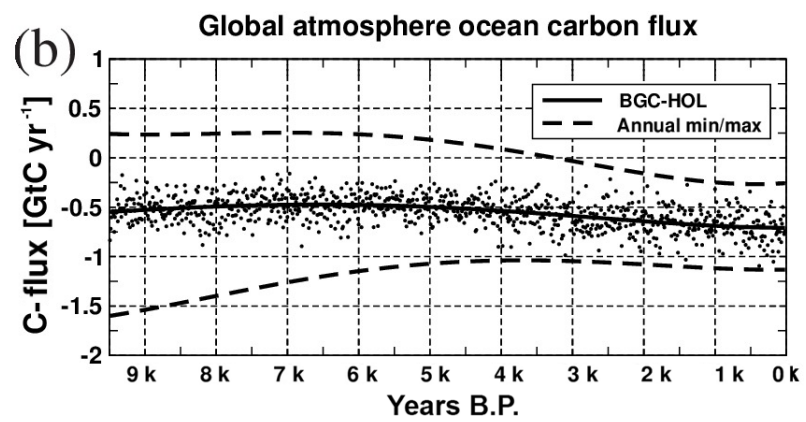

Figure A3. Time series of (a) SST and (b) atmosphere-ocean carbon flux (negative upward) for experiment BGC-HOL (black dots: annual mean values, solid black line: fourth-order polynomial fit), and annual minimum and maximum (dashed black lines, fourth-order polynomial fits), indicating the range of the annual cycle. 


\section{Appendix B: Changes in the seasonal cycle}

Figure A3 demonstrates the increasing amplitude of the seasonal cycle of SST and the decreasing amplitude of the seasonal cycle for the atmosphere-ocean carbon flux during the Holocene. For SST, the annual range increases during the first half of the Holocene from about $0.35^{\circ} \mathrm{C}$ to about $0.7^{\circ} \mathrm{C}$ at $5 \mathrm{kyr} \mathrm{BP}$ and remains at that level for the remainder of the Holocene.

For the atmosphere-ocean carbon flux, the seasonal cycle is almost $2 \mathrm{GtC} \mathrm{yr}^{-1}$ in the early Holocene. It becomes continuously weaker as the Holocene proceeds and is less than $1 \mathrm{GtC} \mathrm{yr}^{-1}$ in the late Holocene. Until $5 \mathrm{kyr}$ BP it is mainly the maximum outgassing that becomes weaker, whereas after $5 \mathrm{kyr}$ BP the maximum uptake decreases and turns into outgassing after $3 \mathrm{kyr}$ BP (keep in mind that PISCES has an equilibrium outgassing of around $0.5 \mathrm{GtC} \mathrm{a}^{-1}$ that compensates for the riverine carbon input). 
Competing interests. The authors declare that they have no conflict of interest.

Special issue statement. This article is part of the special issue "Progress in quantifying ocean biogeochemistry - in honour of Ernst Maier-Reimer". It is not associated with a conference.

Acknowledgements. Joachim Segschneider would like to thank the dearly missed Ernst Maier-Reimer for his countless advice and help, Ernst's perpetual willingness to answer his questions and to discuss scientific issues even beyond office hours - at which time, however, discussions were preferably held not in the office but in more enjoyable surroundings, and strictly had to change subject after the third beer - with a bit of luck to his less known months-long journeys from Germany to India and the Saharan desert by car. This work would not have been possible without him.

The authors acknowledge support by the German Research Foundation through the Collaborative Research Centre ClimateBiogeochemistry Interactions in the Tropical Ocean (SFB754) and the DFG project "Climate impact on marine plankton dynamics during interglacials" (grant DFG SCH 762/3-1) and the Excellence Cluster Future Ocean (grant FO EXC 80/1). We also wish to thank the NEMO/PISCES team for providing their models and general support. Computations were carried out on a NEC-SX-ACE at the computing centre of the Christian-Albrechts-University Kiel, Germany. Finally, the authors wish to acknowledge the use of the Ferret programme for analysis and graphics in this paper. Ferret is a product of NOAA's Pacific Marine Environmental Laboratory.

Edited by: Christoph Heinze

Reviewed by: two anonymous referees

\section{References}

Atwood, A., Wu, E., Frierson, D., Battisti, D., and Sachs, J.: Quantifying Climate Forcings and Feedbacks over the Last Millennium in the CMIP5-PMIP3 Models, J. Clim., 29, 1161-1178, https://doi.org/10.1175/JCLI-D-15-0063.1, 2016.

Augustin, L., Barbante, C., Barnes, P. R. F., Barnola, J.-M., Bigler, M., Castellano, E., Cattani, O., Chappellaz, J. A., Dahl-Jensen, D., Delmonte, B., Dreyfus, G., Durand, G., Falourd, S., Fischer, H., Flückiger, J., Hansson, M. E., Huybrechts, P., Jugie, G., Johnsen, S. J., Jouzel, J., Kaufmann, P. R., Kipfstuhl, S., Lambert, F., Lipenkov, V. Y., Littot, G. C., Longinelli, A., Lorrain, R. D., Maggi, V., Masson-Delmotte, V., Miller, H., Mulvaney, R., Oerlemans, J., Oerter, H., Orombelli, G., Parrenin, F., Peel, D. A., Petit, J.-R., Raynaud, D., Ritz, C., Ruth, U., Schwander, J., Siegenthaler, U., Souchez, R., Stauffer, B., Steffensen, J. P., Stenni, B., Stocker, T. F., Tabacco, I., Udisti, R., van de Wal, R. S. W., van den Broeke, M. R., Wilhelms, F., Winther, J.-G., Wolff, E. W., and Zucchelli, M.: Data from the EPICA Dome C ice core EDC, https://doi.org/10.1594/PANGAEA.728149, supplement to: Augustin, L. et al. (2004): Eight glacial cycles from an Antarctic ice core, Nature, 429, 623-628, https://doi.org/10.1038/nature02599, 2004.
Aumont, O., Maier-Reimer, E., Blain, S., and Monfray, P.: An ecosystem model of the global ocean including $\mathrm{Fe}$, Si, P colimitations, Global Biogeochem. Cy., 17, 1060, https://doi.org/10.1029/2001GB001745, 2003.

Berger, A. and Loutre, M.: Insolation values for the climate of the last 10 million years, Quaternary Sci. Rev., 10, 297-317, https://doi.org/10.1016/0277-3791(91)90033-Q, 1991.

Biastoch, A., Treude, T., Rüpke, L. H., Riebesell, U., Roth, C., Burwicz, E. B., Park, W., Latif, M., Böning, C. W., Madec, G., and Wallmann, K.: Rising Arctic Ocean temperatures cause gas hydrate destabilization and ocean acidification, Geophys. Res. Lett., 38, L08602, https://doi.org/10.1029/2011GL047222, 2011.

Blaschek, M., Renssen, H., Kissel, C., and Thornalley, D.: Holocene North Atlantic Overturning in an atmosphere-ocean-sea ice model compared to proxy-based reconstructions, Paleoceanography, 30, 1503-1524, https://doi.org/10.1002/2015PA002828, 2015.

Bopp, L., Resplandy, L., Orr, J. C., Doney, S. C., Dunne, J. P., Gehlen, M., Halloran, P., Heinze, C., Ilyina, T., Séférian, R., Tjiputra, J., and Vichi, M.: Multiple stressors of ocean ecosystems in the 21st century: projections with CMIP5 models, Biogeosciences, 10, 6225-6245, https://doi.org/10.5194/bg-106225-2013, 2013.

Bopp, L., Resplandy, L., Untersee, A., Le Mezo, P., and Kageyama, M.: Ocean (de)oxygenation from the Last Glacial Maximum to the twenty-first century: insights from Earth System models, Philos. T. R. Soc. Lond., 375, 2102, https://doi.org/10.1098/rsta.2016.0323, 2017.

Braconnot, P., Marzin, C., Grégoire, L., Mosquet, E., and Marti, O.: Monsoon response to changes in Earth's orbital parameters: Comparisons between simulations of the Eemian and of the Holocene, Clim. Past, 4, 281-294, https://doi.org/10.5194/cp-4281-2008, 2008.

Braconnot, P., Harrison, S., Kageyama, M., Bartlein, P., Masson-Delmotte, V., Abe-Ouchi, A., Otto-Bliesner, B., and Zhao, Y.: Evaluation of climate models using paleoclimatic data, Nature Climate Change, 2, 417-424, https://doi.org/10.1038/nclimate1456, 2012.

Brovkin, V., Lorenz, S., Jungclaus, J., Raddatz, T., Timmreck, C., Reick, C., Segschneider, J., and Six, K.: Sensitivity of a coupled climate-carbon cycle model to large volcanic eruptions during the last millennium, Tellus B, 62, 674-681, 2010.

Brovkin, V., Brücher, T., Kleinen, T., Zaehle, S., Joos, F., Roth, R., Spahni, R., Schmitt, J., Fischer, H., Leuenberger, M., Stone, E. J., Ridgwell, A., Chappellaz, J., Kehrwald, N., Barbante, C., Blunier, T., and Dahl-Jensen, D.: Comparative carbon cycle dynamics of the present and last interglacial, Quaternary Sci. Rev., 137, 15-32, https://doi.org/10.1016/j.quascirev.2016.01.028, 2016.

Cabré, A., Marinov, I., Bernardello, R., and Bianchi, D.: Oxygen minimum zones in the tropical Pacific across CMIP5 models: mean state differences and climate change trends, Biogeosciences, 12, 5429-5454, https://doi.org/10.5194/bg-12-54292015, 2015.

Cocco, V., Joos, F., Steinacher, M., Frölicher, T. L., Bopp, L., Dunne, J., Gehlen, M., Heinze, C., Orr, J., Oschlies, A., Schneider, B., Segschneider, J., and Tjiputra, J.: Oxygen and indicators of stress for marine life in multi-model global warming projections, Biogeosciences, 10, 1849-1868, 2013. 
Dahl-Jensen, D., Mosegaard, K., Gundestrup, N., Clow, G., Johnsen, S., Hansen, A., and Balling, N.: Past Temperatures Directly from the Greenland Ice Sheet, Science, 282, 268-271, 1998.

Deutsch, C., Brix, H., Ito, T., Frenzel, H., and Thompson, L.: Climate-forced variability of ocean hypoxia, Science, 333, 336339, https://doi.org/10.1126/science.1202422, 2011.

Ducklow, H., Steinberg, D., and Buesseler, K.: Upper Ocean Carbon Export and the Biological Pump, Oceanography, 14, 50-58, 2001.

Elsig, J., Schmitt, J., Leuenberger, D., Schneider, R., Eyer, M., Leuenberger, M., Joos, F., Fischer, H., and Stocker, T.: Stable isotope constraints on Holocene carbon cycle changes from an Antarctic ice core, Nature, 461, 507-510, https://doi.org/10.1038/nature08393, 2009.

Emile-Geay, J., Cobb, K. M., Carre, M., Braconnot, P., Leloup, J., Zhou, Y., Harrison, S., Correge, T., McGregor, H., Collins, M., Driscoll, R., Elliot, M., Schneider, B., and Tudhope, A.: Links between tropical Pacific seasonal, interannual and orbital variability during the Holocene, Nat. Geosci., 9, 168-173, https://doi.org/10.1038/NGEO2608, 2016.

Fichefet, T. and Morales Maqueda, M.: Sensitivity of a global sea ice model to the treatment of ice thermodynamics and dynamics, J. Geophys. Res., 102, 12609-12646, 1997.

Fischer, N. and Jungclaus, J. H.: Evolution of the seasonal temperature cycle in a transient Holocene simulation: orbital forcing and sea-ice, Clim. Past, 7, 1139-1148, https://doi.org/10.5194/cp-71139-2011, 2011.

Garcia, H. E., Locarnini, R. A., Boyer, T. P., Antonov, J. I., Baranova, O. K., Zweng, M. M., Reagan, J. R., and Johnson, D. R.: World Ocean Atlas 2013, Volume 3: Dissolved Oxygen, Apparent Oxygen Utilization, and Oxygen Saturation, edited by: Levitus, S., A. Mishonov, Technical Ed., NOAA Atlas NESDIS 75, US Government Printing Office, Washington, DC, 2013.

Gaye, B., Böll, A., Segschneider, J., Burdanowitz, N., Emeis, K.-C., Ramaswamy, V., Lahajnar, N., Lückge, A., and Rixen, T.: Glacial-Interglacial changes and Holocene variations in Arabian Sea denitrification, Biogeosciences, 15, 507-527, https://doi.org/10.5194/bg-15-507-2018, 2017.

Gehlen, M., Bopp, L., Emprin, N., Aumont, O., Heinze, C., and Ragueneau, O.: Reconciling surface ocean productivity, export fluxes and sediment composition in a global biogeochemical ocean model, Biogeosciences, 3, 521-537, https://doi.org/10.5194/bg-3-521-2006, 2006.

Heinze, C., Maier-Reimer, E., and Winn, K.: Glacial $p \mathrm{CO}_{2}$ reduction by the World Ocean: Experiments with the Hamburg carbon cycle model, Paleoceanography, 395-430, 6, 1991.

Hoogakker, B. A. A., Chapman, M. R., McCave, I. N., Hillaire-Marcel, C., Ellison, C. R. W., Hall, I. R., and Telford, R. J.: Dynamics of North Atlantic Deep Water masses during the Holocene, Paleoceanography, 26, PA4214, https://doi.org/10.1029/2011PA002155, 2011.

Indermühle, A., Stocker, T., Joos, F., Fischer, H., Smith, H., Wahlen, M., Deck, B., Mastroianni, D., Tschumi, J., Blunier, T., Meyer, R., and Staufer, B.: Holocene carbon-cycle dynamics based on $\mathrm{CO}_{2}$ trapped in ice at Taylor Dome, Antarctica, Nature, 398, 121-126, 1999.

IPCC: Climate Change 2007, in: The Physical Science Basis - Contribution of Working Group I to the Fourth Assessment Report of the Intergovernmental Panel on Climate Change, edited by: Solomon, S., Qin, D., and Manning, M., Cambridge Univ. Press, Cambridge, UK, 663-745, 2007.

Jaccard, S. and Galbraith, E.: Large climate-driven changes of oceanic oxygen concentrations during the last deglaciation, Nat. Geosci., 5, 151-156, https://doi.org/10.1038/ngeo1352, 2012.

Jin, L., Schneider, B., Park, W., Latif, M., and Khon, V.: The spatialtemporal pattern of Asian summer monsoon precipitation in response to Holocene insolation change: a model-data synthesis, Quaternary Sci. Rev., 85, 47-62, 2014.

Jungclaus, J. H., Lorenz, S. J., Timmreck, C., Reick, C. H., Brovkin, V., Six, K., Segschneider, J., Giorgetta, M. A., Crowley, T. J., Pongratz, J., Krivova, N. A., Vieira, L. E., Solanki, S. K., Klocke, D., Botzet, M., Esch, M., Gayler, V., Haak, H., Raddatz, T. J., Roeckner, E., Schnur, R., Widmann, H., Claussen, M., Stevens, B., and Marotzke, J.: Climate and carbon-cycle variability over the last millennium, Clim. Past, 6, 723-737, https://doi.org/10.5194/cp-6-723-2010, 2010.

Karstensen, J., Stramma, L., and Visbeck, M.: Oxygen minimum zones in the eastern tropical Atlantic and Pacific Oceans, Prog. Oceanogr., 77, 331-350, 2008.

Khon, V. C., Park, W., Latif, M., Mokhov, I. I., and Schneider, B.: Response of the hydrological cycle to orbital and greenhouse gas forcing, Geophys. Res. Lett., 37, L19705, https://doi.org/10.1029/2010GL044377, 2010.

Khon, V. C., Park, W., Latif, M., Mokhov, I. I., and Schneider, B.: Tropical circulation and hydrological cycle response to orbital forcing, Geophys. Res. Lett., 39, L15708, https://doi.org/10.1029/2012GL052482, 2012.

Laskar, J., Robutel, P., Joutel, F., Gastineau, M., Correia, A. C. M., and Levrard, B.: A long-term numerical solution for the insolation quantities of the Earth, Astron. Astrophys., 428, 261-285, https://doi.org/10.1051/0004-6361:20041335, 2004.

Leduc, G., Schneider, R., Kim, J. H., and Lohmann, G.: Holocene and Eemian sea surface temperature trends as revealed by alkenone and $\mathrm{Mg}$ / Ca paleothermometry, Quateranry Sci. Rev., 29, 989-1004, https://doi.org/10.1016/j.quascirev.2010.01.1004, 2010.

Lehner, F., Joos, F., Raible, C., Mignot, J., Born, A., Keller, K., and Stocker, T.: Climate and carbon cycle dynamics in a CESM simulation from 850 to 2100 CE, Earth Syst. Dynam., 6, 411434, https://doi.org/10.5194/esd-6-411-2015, 2015.

Liu, Z., Zhu, J., Rosenthal, Y., Zhang, X., Otto-Bliesner, B. L., Timmermann, A., Smith, R. S., Lohmann, G., Zheng, W., and Elison Timm, O.: The Holocene temperature conundrum, P. Natl. Acad. Sci. USA, 111, E3501-E3505, https://doi.org/10.1073/pnas.1407229111, 2014.

Locarini, R., Mishonov, A. V., Antonov, J., Boyer, T., Garcia, H., Baranova, O., Zweng, M., Paver, C., Reagan, J., Johnson, D., Hamilton, M., and Seidov, D.: World Ocean Atlas 2013, Volume 1: Temperature, edited by: Levitus, S., A. Mishonov, Technical Ed., NOAA Atlas NESDIS 73, 2013.

Lorenz, S. J. and Lohmann, G.: Acceleration technique for Milankovitch type forcing in a coupled atmosphere-ocean circulation model: method and application for the Holocene, Clim. Dynam., 23, 727-743, 2004.

Madec, G.: NEMO ocean engine, Note du Pôle de Modélisation 27, Inst. Pierre - Simon Laplace, Paris, 2008. 
Maier-Reimer, E.: Geochemical cycles in an ocean general circulation model: Preindustrial tracer distributions, Global Biogeochem. Сy., 7, 645-677, 1993.

Maier-Reimer, E. and Hasselmann, K.: Transport and storage of $\mathrm{CO}_{2}$ in the ocean - An inorganic ocean-circulation carbon cycle model, Clim. Dynam., 2, 63-90, 1987.

Maier-Reimer, E., Mikolajewicz, U., and Hasselmann, K.: Mean Circulation of the Hamburg LSG OGCM and its Sensitivity to the Thermohaline Surface Forcing, J. Phys. Oceanogr., 23, 731757, 1993.

Maier-Reimer, E., Mikolajewicz, U., and Winguth, A.: Future ocean uptake of $\mathrm{CO}_{2}$ : Interaction between ocean circulation and biology, Clim. Dynam., 12, 711-721, 1996.

Maier-Reimer, E., Kriest, I., Segschneider, J., and Wetzel, P.: The HAMburg Ocean Carbon Cycle model HAMOCC5.1 - Technical description Release 1.1, Reports on Earth System Science 14, Max Planck Institute for Meteorology, 2005.

Marchal, O., Cacho, I., Stocker, T. F., Grimalt, J. O., Calvo, E., Martrat, B., Shackleton, N., Vautravers, M., Cortijo, E., van Kreveld, S., Andersson, C., Ko, N., Chapman, M., Sbaffi, L., Duplessy, J.-C., Sarnthein, M., Turon, J.-L., Duprat, J., and Jansen, E.: Apparent long-term cooling of the sea surface in the northeast Atlantic and Mediterranean during the Holocene, Quaternary Sci. Rev., 21, 455-483, https://doi.org/10.1016/S02773791(01)00105-6, 2002.

Marcott, S., Shakun, J. D., Clark, P., and Mix, A.: A reconstruction of regional and global temperature for the past 11,300 years, Science, 339, 1189, https://doi.org/10.1126/science.1228026, 2013.

Martin, J. H., Knauer, G. A., Karl, D. M., and Broenkow, W. W.: VERTEX: carbon cycling in the northeast Pacific, Deep-Sea Res., 34, 267-286, 1987.

Matear, R. J. and Hirst, C.: Long-term changes in dissolved oxygen concentrations in the ocean caused by protracted global warming, Global Biogeochem. Cy., 17, 1125, https://doi.org/10.1029/2002GB001997, 2003.

Moffitt, S. E., Moffitt, R. A., Sauthoff, W., Davis, C. V., Hewett, K., and Hill, T. M.: Paleoceanographic Insights on Recent Oxygen Minimum Zone Expansion: Lessons for Modern Oceanography, PLoS ONE, 10, e0115246, https://doi.org/10.1371/journal.pone.0115246, 2015.

PAGES 2k Consortium: Continental-scale temperature variability during the past two millennia, Nat. Geosci., 6, 339-346, https://doi.org/10.1038/ngeo1797, 2013.

Park, W. and Latif, M.: Multidecadal and Multicentennial Variability of the Meridional Overturning Circulation, Geophys. Res. Lett., 35, L22073, https://doi.org/10.1029/2008GL035779, 2008.

Park, W., Keenlyside, N., Latif, M., Ströh, A., Redler, R., Roeckner, E., and Madec, G.: Tropical Pacific Climate and its Response to Global Warming in the Kiel Climate Model, J. Clim., 22, 71-92, https://doi.org/10.1175/2008JCLI2261.1, 2009.

Renssen, H., Goosse, H., and Fichefet, T.: Contrasting trends in North Atlantic deep-water formation in the Labrador Sea and Nordic Seas during the Holocene, Geophys. Res. Lett., 32, L08711, https://doi.org/10.1029/2005GL022462, 2005.

Renssen, H., Seppä, H., Heiri, O., Roche, D. M., Goosse, H., and Fichefet, T.: The spatial and temporal complexity of the Holocene thermal maximum, Nat. Geosci., 2, 411-414, https://doi.org/10.1038/ngeo513, 2009.
Roeckner, E., Bäuml, G., Bonaventura, L., Brokopf, R., Esch, M., Giorgetta, M., Hagemann, S., Kirchner, I., Kornblueh, L., Manzini, E., Rhodin, A., Schlese, U., Schulzweida, U., and Tompkins, A.: The atmospheric general circulation model ECHAM5, Part I: Model description, Report 349, Max Planck Inst. for Meteorol., Hamburg, Germany, 2003.

Salau, O. R., Schneider, B., Park, W., Khon, V., and Latif, M.: Modeling the ENSO impact of orbitally induced mean state climate changes, J. Geophys. Res.-Ocean., 117, C05043, https://doi.org/10.1029/2011JC007742, 2012.

Salvatteci, R., Gutierrez, D., Sifeddine, A., Ortlieb, L., Druffel, E., Boussafir, M., and Schneider, R.: Centennial to millennial-scale changes in oxygenation and productivity in the Eastern Tropical South Pacific during the last 25000 years, Quaternary Sci. Rev., 131, 102-117, 2016.

Sarmiento, J. and Gruber, N.: Ocean Biogeochemical Dynamics, Princeton University Press, 2006.

Schmidtko, S., Stramma, L., and Visbeck, M.: Decline in global oceanic oxygen content during the past five decades, Nature, 542 , 335-339, https://doi.org/10.1038/nature21399, 2017.

Schmittner, A., Galbraith, E., Hostetler, S., Pedersen, T., and Zhang, R.: Large fluctuations of dissolved oxygen in the Indian and Pacific ocean during DansgaardOeschger oscillations caused by variations of North Atlantic Deep Water subduction, Paleoceanography, 22, PA3207, https://doi.org/10.1029/2006PA001384, 2007.

Schneider, B., Leduc, G., and Park, W.: Disentangling seasonal signals in Holocene climate trends by satellitemodel-proxy integration, Paleoceanography, 25, PA4217, https://doi.org/10.1029/2009PA001893, 2010.

Segschneider, J. and Bendtsen, J.: Temperature-dependent remineralization in a warming ocean increases surface $\mathrm{pCO}_{2}$ through changes in marine ecosystem composition, Global Bigeochem. Cy., 27, 1214-1225, https://doi.org/10.1002/2013GB004684, 2013.

Six, K. and Maier-Reimer, E.: Effects of plankton dynamics on seasonal carbon fluxes in a ocean general circulation model, Global Biogeochem. Cy., 10, 559-583, 1996.

Steinacher, M., Joos, F., Frölicher, T. L., Bopp, L., Cadule, P., Cocco, V., Doney, S. C., Gehlen, M., Lindsay, K., Moore, J. K., Schneider, B., and Segschneider, J.: Projected 21st century decrease in marine productivity: a multi-model analysis, Biogeosciences, 7, 979-1005, https://doi.org/10.5194/bg-7-979-2010, 2010.

Stramma, L., Johnson, G. C., Sprintall, J., and Mohrholz, V.: Expanding oxygen minimum zones in the tropical oceans, Science, 320, 655-685, 2008.

Varma, V., Prange, M., Merkel, U., Kleinen, T., Lohmann, G., Pfeiffer, M., Renssen, H., Wagner, A., Wagner, S., and Schulz, M. Holocene evolution of the Southern Hemisphere westerly winds in transient simulations with global climate models, Clim. Past, 8, 391-402, https://doi.org/10.5194/cp-8-391-2012, 2012.

Varma, V., Prange, M., and Schulz, M.: Transient simulations of the present and the last interglacial climate using the Community Climate System Model version 3: effects of orbital acceleration, Geosci. Model Dev., 9, 3859-3873, https://doi.org/10.5194/gmd9-3859-2016, 2016.

Vecsei, A. and Berger, W. H.: Increase of atmospheric $\mathrm{CO}_{2}$ during deglaciation: Constraints on the coral reef hypothesis from 
patterns of deposition, Global Biogeochem. Cy., 18, GB1035, https://doi.org/10.1029/2003GB002147, 2004.

Vieira, L., Solanki, S., Krivova, N., and Usoskin, I.: Evolution of the solar irradiance during the Holocene, Astron. Astrophys., 531, https://doi.org/10.1051/0004-6361/201015843, 2011.

Wanner, H., Beer, J., Bütikofer, J., Crowley, T. J., Cubasch, U., Flückiger, J., Goosse, H., Grosjean, M., Joos, F., Kaplan, J. O., Küttel, M., Müller, S. A., Prentice, I. C., Solomina, O., Stocker, T. F., Tarasov, P., Wagner, M., and Widmann, M.: Mid- to Late Holocene climate change: an overview, Quaternary Sci. Rev., 27, 1791-1828, https://doi.org/10.1016/j.quascirev.2008.06.013, 2008.
Xu, X., Segschneider, J., Schneider, B., Park, W., and Latif, M.: Oxygen minimum zone variations in the tropical Pacific during the Holocene, Geophys. Res. Lett., 42, 8530-8537, https://doi.org/10.1002/2015GL064680, 2015. 